\title{
Jeochemical Aspects of
}

Artificial Recharge in the

Jrand Prairie Region

\section{Arkansas}

R. T. SNIEGOCKI

?TIFICIAL RECHARGE OF GROUND WATER-GRAND PRAIRIE REGION, ARKANSAS

3EOLOGICAL SURVEY WATER-SUPPLY PAPER 1615-E

"repared in cooperation with the

-S. Army Corps of Engineers ind the Agricultural Experiment "tation, University of Arkansas

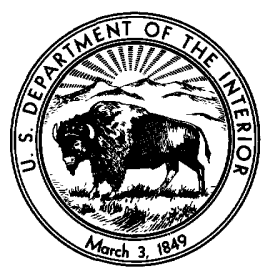




\section{UNITED STATES DEPARTMENT OF THE INTERIOR}

STEWART L. UDALL, Secretary

\section{GEOLOGIGAL SURVEY}

Thomas B. Nolan, Director 


\section{CONTENTS}

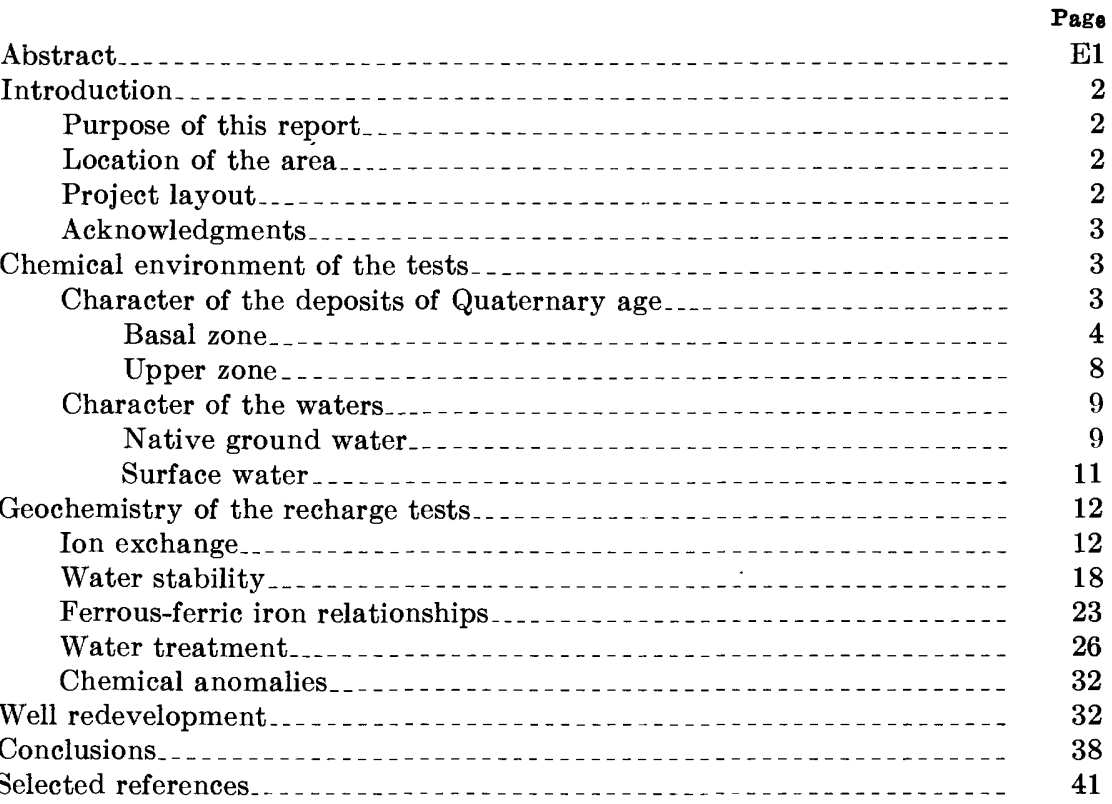

\section{ILLUSTRATIONS}

Plate 1. Hydrograph of the water level in an observation well 20 feet from the recharge well. ............ In pocket

Figure 1. Map of Arkansas showing the location of the Grand Prairie Page region

2. Map of the artificial-recharge area

3. Map showing layout of equipment.

4. Aerial photograph of the test site

5. Linear pattern diagram showing range of concentrations of principal constituents of samples of native ground water

6. Linear-pattern diagram showing range of concentrations of principal constituents of the water injected during test 19

7. Stability-field diagram for aqueous ferric-ferrous system . ..... 24 


\section{TABLES}

TABLe 1. Chemical analyses of water from Hoskyn reservoir

Page

2. Summary of part of the data collected during recharge tests 2 , 4 , and 20

3. Chemical analyses of water samples collected during recharge tests 2, 4, and 20

4. Chemical analyses of water samples collected during recharge test 3

E11

5. Chemical analyses of samples of the surface water used for injection during recharge tests 4 and $5 \ldots$ 


\title{
ARTIFICIAL RECHARGE OF GROUND WATER-GRAND PRAIRIE REGION, ARKANSAS
}

\section{GEOCHEMICAL ASPEGTS OF ARTIFICIAL RECHARGE}

\author{
By R. T. SNIEGOCKI
}

\begin{abstract}
Chemical changes in the injected water and native ground water during artificial recharge through a well have an important bearing on the success or failure of recharge-well operation. Water stability and changes in chemical quality of the water that may be caused by changed environment should be examined critically when contemplating recharge. In this study the principal chemical changes observed that may cause clogging of the recharge well and aquifer were a change in calcium carbonate saturation of the injected and native water, whereby the calcium carbonate precipitated; precipitation of iron when reducing and oxidizing waters are mixed; ion exchange and clay dispersion; and changes in water stability caused by water treatment.
\end{abstract}

The native ground water at the test site was stable with respect to its environment. However, the injected water tended to pick up carbon dioxide as it moved through the aquifer. Native ground water would readjust to the changed environment upon reentry into the zone of carbon dioxide depletion causing deposition of calcium carbonate.

The Eh $-\mathrm{pH}$ relationship of the native ground water and recharge water could cause iron to be precipitated as ferric hydroxide at the interface of the ground water and injected water in the aquifer. Incomplete removal of the injected water would tend to cause an accumulation of precipitated iron in the aquifer, eventually plugging a large volume of material.

The native ground water averaged about 25 percent sodium and in the injection supply averaged about 45 percent. Surface water injected into the aquifer would would displace the native ground water and increase the abundance of monovalent cations surrounding aquifer materials, thus creating favorable conditions for ion exchange. However, most of the aquifer materials are chemically inert, and clay dispersal caused by ion exchange probably was not a serious clogging factor.

The chemical treatment of surface water by coagulation with alum and chlorination with chlorine gas caused most of the changes in chemical quality. Although the treated water may have been stable with respect to its aluminum content in the settling canal, mixing with the native ground water in the aquifer could alter the $\mathrm{pH}$ and alkalinity of the two solutions. This would cause postinjection flocculation of residual aluminum and subsequent clogging of the aquifer. Heavy chlorination of the injected water also may cause clogging owing to precipitation of iron and other metals. Dissolved iron and organic matter are easily oxidized by chlorine. Iron precipitated in this manner would tend to lower aquifer per- 
meability, and oxidation of organic matter would release gases, leading to air entrainment.

Well redevelopment is an important phase in water injection and may provide the means for economical and practical operation of a recharge well.

\section{INTRODUCTION}

\section{PURPOSE OF THIS REPORT}

In 1953 the Grand Prairie region of Arkansas was selected for an investigation of fundamental principles of recharging ground-water reservoirs through wells. The investigation consisted of collecting detailed hydrogeologic information in the vicinity of the recharge site, drilling two recharge wells, constructing water-treatment and conveyance facilities, and making a series of tests by injecting water into the two wells. This report, one of a series covering separate elements of the project, was prepared as the data and interpretative analyses became available. Its purpose is to present information about the geochemical changes observed in the native ground water, injected water, and aquifer during recharge tests; potential recharge problems caused by chemical phenomena; and the results of redevelopment tests made on the recharge wells.

\section{LOCATION OF THE AREA}

The Grand Prairie region in east-central Arkansas is in the Mississippi Alluvial Plain section of the Coastal Plain. The region is an irregular but continuous tract of prairie lying between the White River and Bayou Meto. It extends northwestward, from near the confluence of the White and Arkansas Rivers to a short distance beyond Lonoke in Lonoke County. Nearly all of Arkansas County and parts of Lonoke, Prairie, and Monroe Counties are included in the Grand Prairie region. (See fig. 1.) The Grand Prairie includes approximately 1,000 square miles, of which roughly 700 square miles or 450,000 acres is developed riceland.

The project area includes about 210 square miles of land in Arkansas County (fig. 2). The Rice Branch Experiment Station of the University of Arkansas is near the center of the area and is the site of the artificial-recharge tests.

\section{PROJECT LAYOUT}

A brief description of the physical layout of equipment and control points is needed to understand the geochemical aspects of the study. Samples of water for chemical analysis were collected from one or more observation wells at different distances from the recharge wells. Samples of water were collected also from different points along the water-treatment system. The layout of the project is shown in figures 3 and 4 . 


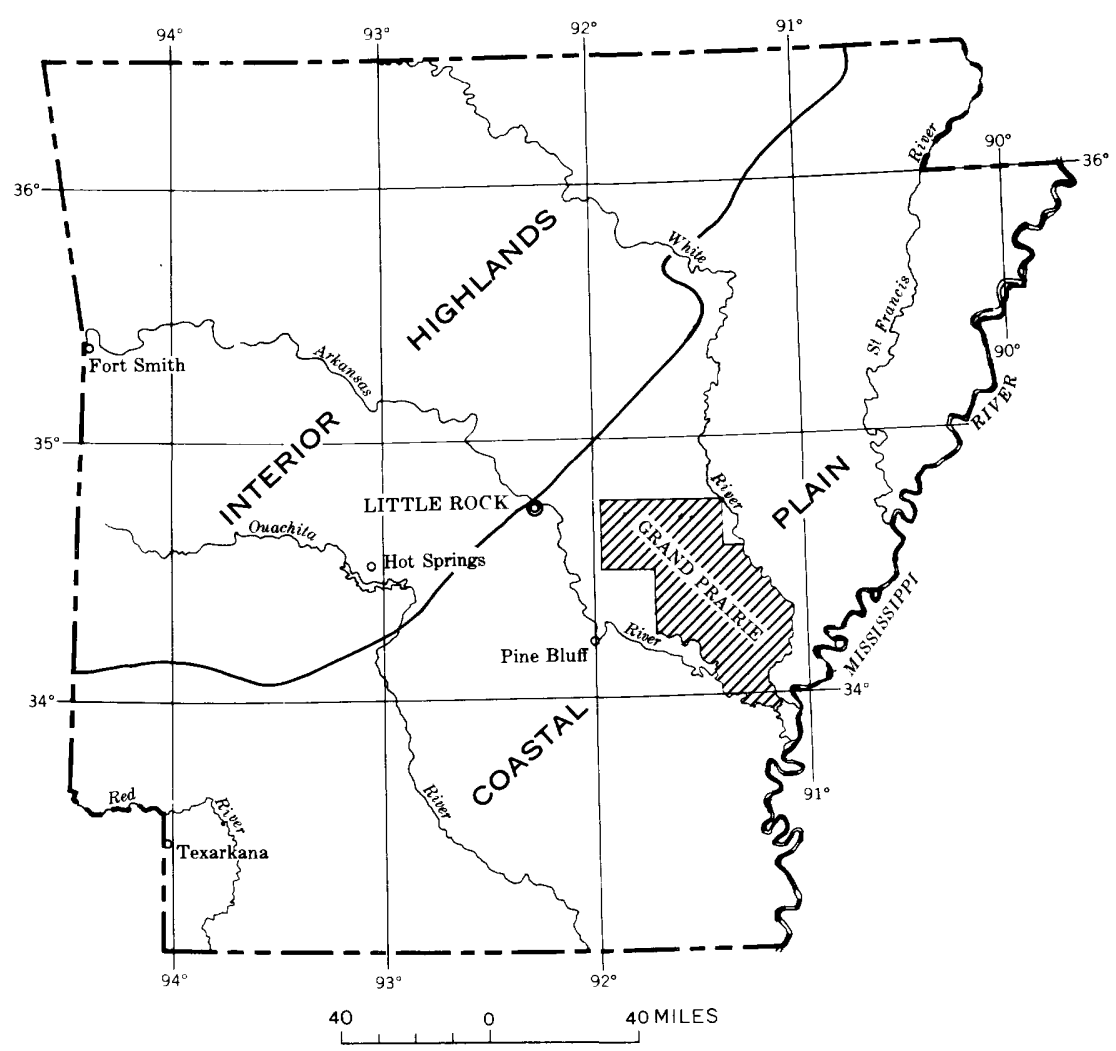

Figure 1.-Map of Arkansas showing the location of the Grand Frairie region.

Equipment specifications and control points are discussed in another report in this series by Sniegocki and others (1963).

\section{ACKNOWLEDGMENTS}

The cooperation, assistance, and advice given by many Federal, State, and city agencies, companies, and individuals are gratefully acknowledged. Special thanks are given to J. D. Hem for his assistance in interpretation of the chemical-quality data and technical review of this report.

\section{CHEMICAL ENVIRONMENT OF THE TESTS}

\section{CHARACTER OF THE DEPOSITS OF QUATERNARY AGE}

All recharge tests made during this investigation utilized wells constructed in alluvial deposits of Quaternary age. The alluvium at the test site consists of two zones - a basal zone of mixed sand and gravel about 74 feet thick and an upper zone of silt and clay about 55 feet 


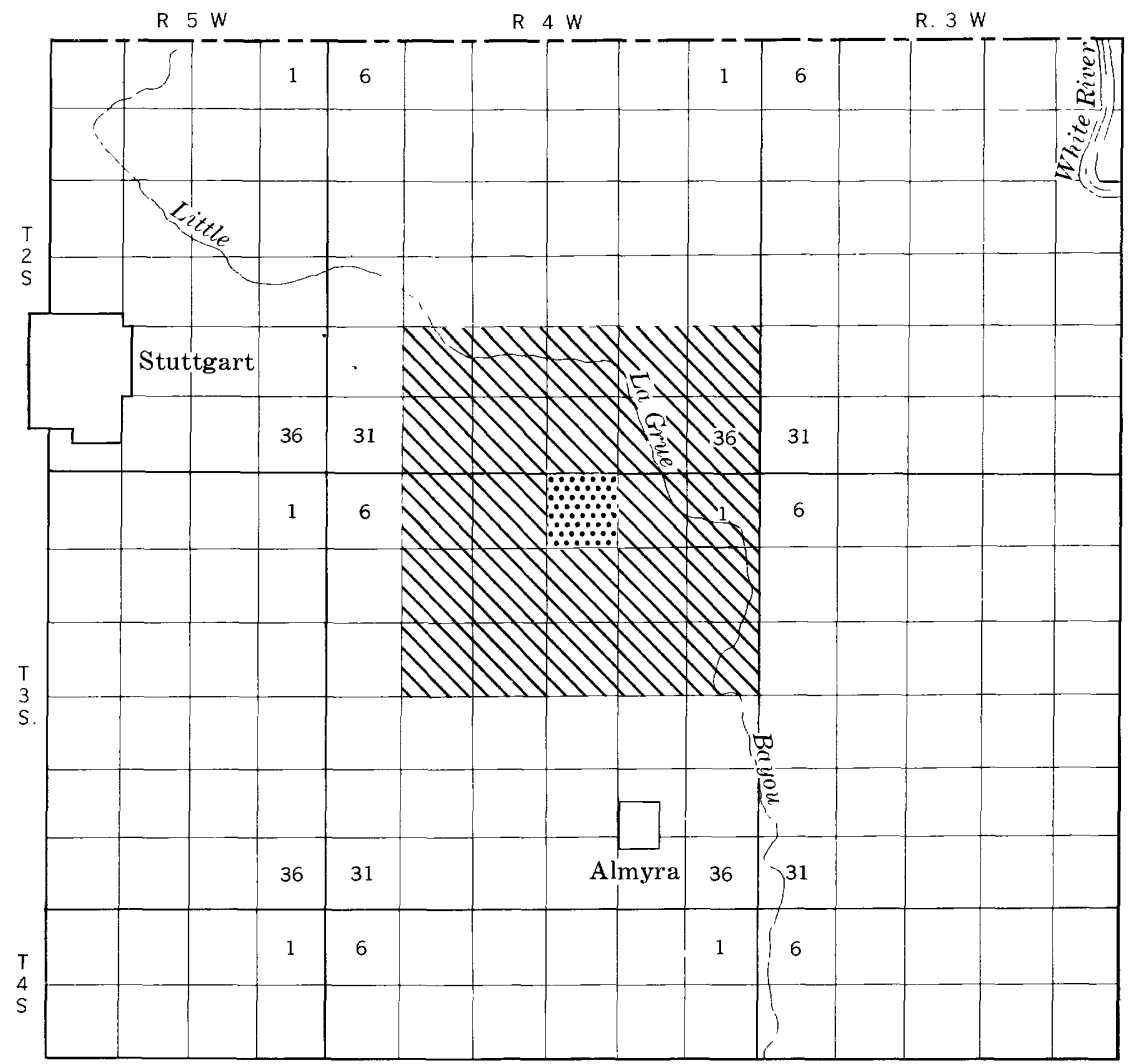

EXPLANATION

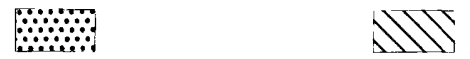

University of Arkansas, Area arbitrarily considered Rice Branch Experiment as likely to be affected by the artificial recharge Station, site of the recharge tests test

Area studied for control

Fig URe 2.-Map of the artificial-recharge area showing the site of the tests.

thick. Both zones overlie deposits of Tertiary age. A detailed description of the geology at the test site is given in another report in this series (Sniegocki, 1963).

\section{BASAL ZONE}

The basal zone is predominantly quartz sand. Small bodies of gravel scattered throughout the basal zone consist of chert, chalcedonic rocks, orthoquartzite, metaquartzite, quartz, and felsitic igneous rocks. These materials are relatively stable and chemically inert and probably were not involved directly in chemical changes during recharge. 


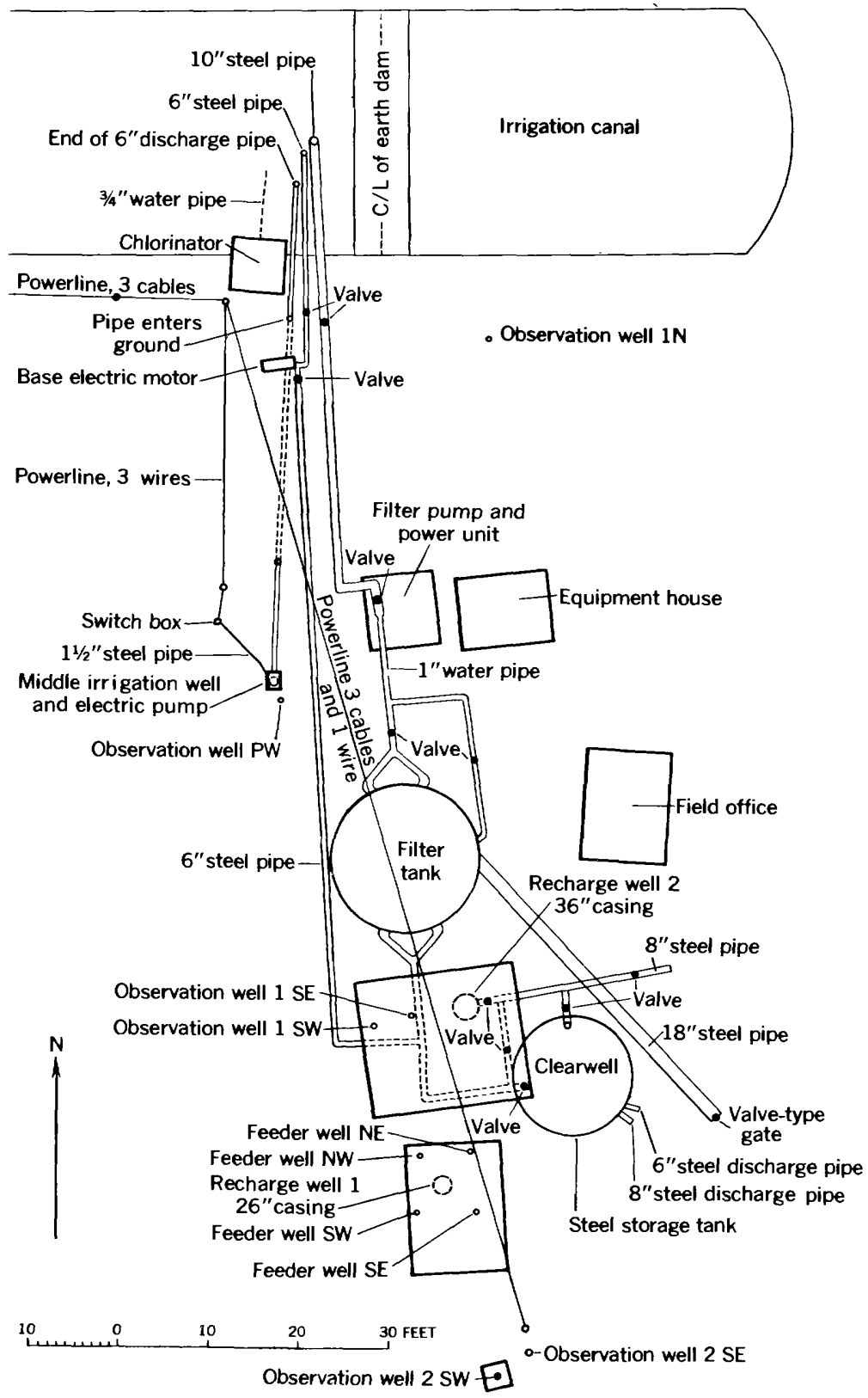

FIGURE 3.-Map of the artificial-recharge site showing layout of equipment. 


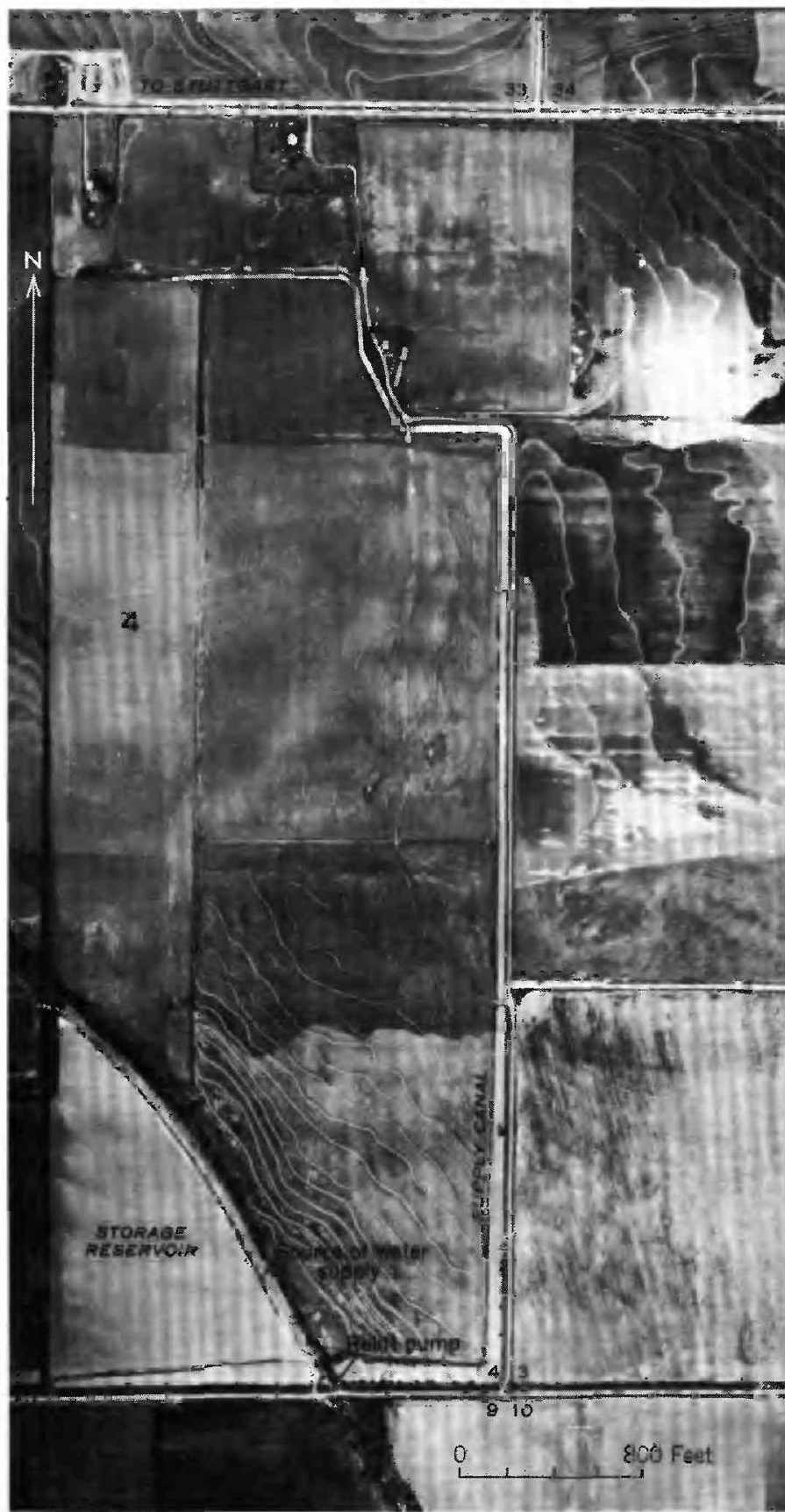

FIGURE 4.-Aerial photograph of the test site, 1960. 
Minor amounts of sand-size shell fragments are scattered through the quartz sand. These grains were recognized readily by testing a sand sample with dilute hydrochloric acid. Although shell fragments are not the dominant material in the basal zone, they were involved in chemical changes during recharge.

Several thin discontinuous clay, silt, and clay-ball lenses are interbedded in the basal zone. X-ray analysis was used to determine the mineral content of samples of these lenses collected during test drilling (Sniegocki, 1963). Quartz was the dominant mineral; minor amounts of feldspar and traces of montmorillonite, mica, and kaolinite also were identified.

The clay balls are dark reddish brown, very hard, slightly flattened, and have well-rounded edges. They probably originated as chunks of clay dislodged from cliffs along stream channels. The balls do not readily absorb water, and even though samples were collected from the zone of saturation, they appeared nearly dry inside. Because of their induration and low water content, the clay balls probably had no chemical effect during recharge tests.

Small amounts of organic material were identified in some of the lenses, and a mucky odor was noticeable in fresh samples. Minor amounts of lignite fragments also were scattered throughout the sand. These materials may have undergone chemical changes during recharge, but no analysis of the organic content of the clay lenses was made.

\section{UPPER ZONE}

The upper zone consists of a very dense, relatively impervious darkreddish-brown clay layer overlain and underlain by layers of tan, gray, blue, red, and brown clay and silt. The layers generally range in thickness from 5 to 60 feet over much of the prairie and are about 55 feet thick at the recharge site.

The dark-reddish-brown clay grades laterally to a dark-reddishbrown or salmon-red very fine to fine silt and sand. 'The sand grains are composed dominantly of quartz and are colored red by stains and coatings of iron oxide.

Generally, a marked change from noncalcareous to calcareous material was observed in the upper few feet of the dark-reddish-brown clay. An examination of test-hole cuttings at the recharge site showed the Quaternary deposits to be calcareous below a depth of about 12 feet.

Shell fragments, calcareous concretions and nodules, and wood and charcoal fragments are found in the upper zone at several depths. Commonly, the calcareous concretions are 10 to 15 feet below the horizon at which the sediments become calcareous. The silty zones commonly contain flakes of mica. 
X-ray analysis was used to determine the mineral content of samples from the upper zone (Sniegocki, 1963). Montmorillonite was the dominant clay mineral although there was much feldspar; there was more orthoclase feldspar than plagioclase. Small amounts of illite and kaolinite also were observed.

\section{CHARACTER OF THE WATERS}

\section{NATIVE GROUND WATER}

Chemical analyses of ground water collected at periodic intervals from wells at and near the project site showed that the waters were of the calcium bicarbonate type (Sniegocki, 1963). The range of concentrations of 6 major ions in 42 samples of native ground water collected from wells at and near the project site is shown in figure 5 . The analysis of a typical sample of native ground water follows, with ionic concentrations reported in parts per million.

Field data:

Date of collection

Water temperature $\left({ }^{\circ} \mathrm{F}\right) \ldots$

Silica $\left(\mathrm{SiO}_{2}\right) \ldots$

Cations-heavy metal ions:

Aluminum $(\mathrm{Al})$

Iron $(\mathrm{Fe})$

Copper $(\mathrm{Cu}) \ldots 0$

Cations-alkali earths and metals:

Calcium (Ca) _...

Magnesium (Mg)

Sodium (Na)

Potassium $(\mathrm{K}) \ldots \ldots \ldots$

Anions:

Bicarbonate $\left(\mathrm{HCO}_{3}\right) \ldots$

Sulfate $\left(\mathrm{SO}_{4}\right) \ldots$

Chloride (Cl)

Fluoride (F)

Nitrate $\left(\mathrm{NO}_{3}\right)_{1} \ldots \ldots$

Phosphate $\left(\mathrm{PO}_{4}\right)$

Organic, nonionic, and calculated values:

Dissolved solids, residue on evaporation at $180^{\circ} \mathrm{C}$, in ppm _... . . 496

Hardness as $\mathrm{CaCO}_{3}$ (calcium and magnesium) _........... 340

Noncarbonate hardness._._.

Percent sodium

Other data:

Specific conductance (micromhos at $25^{\circ} \mathrm{C}$ ) $\ldots \ldots \ldots 6$

pH _. . 7.

The native ground water at the recharge site is clear and nearly odorless, and samples analyzed by the Arkansas State Health Department indicated that the water was safe for drinking at the time of sampling. 


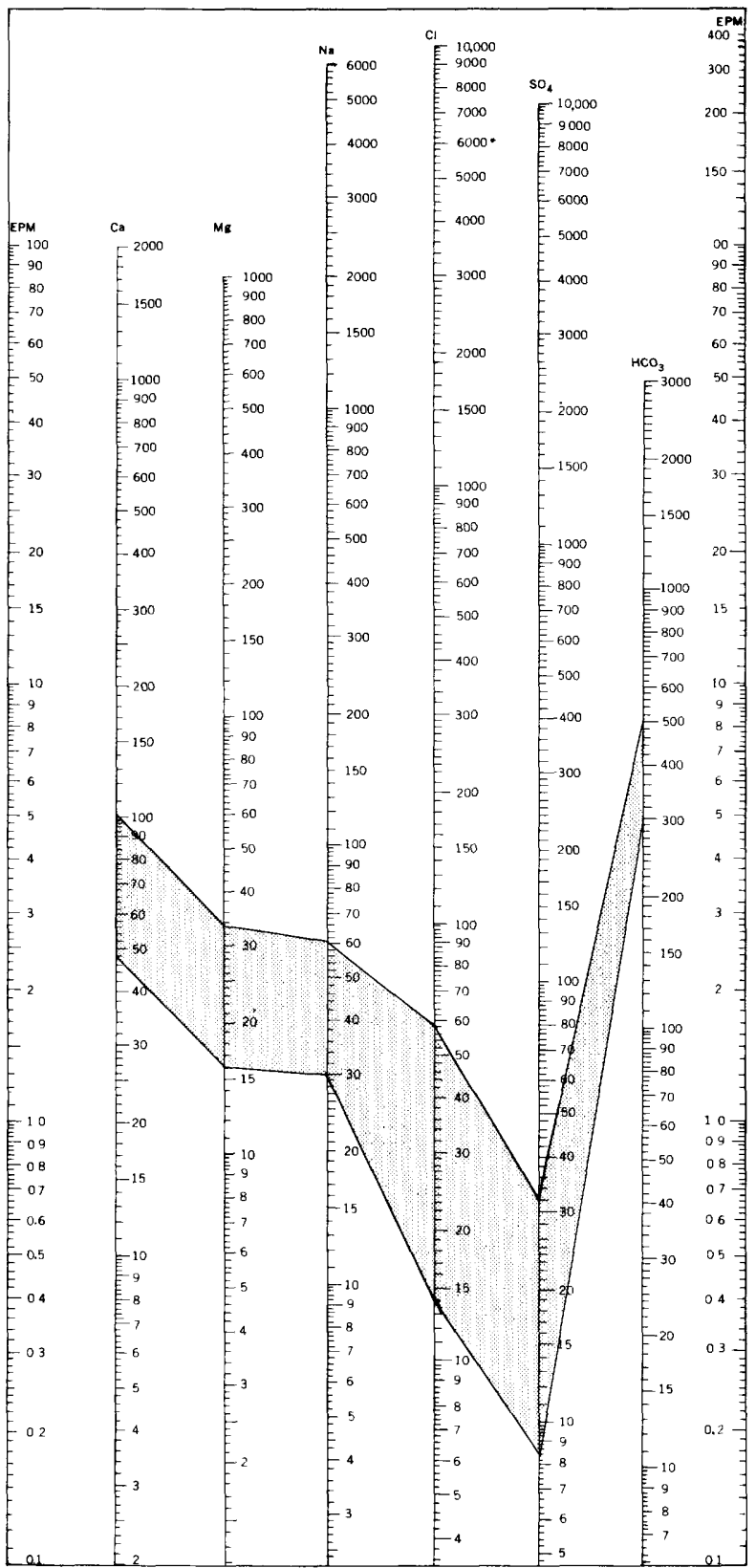

FIGURE 5.-Linear pattern diagram showing the range of concentrations, in parts per million, of the principal constituents of samples of native ground water collected at and near the project site. 
The $\mathrm{pH}$ of the water tends to increase on standing in contact with air, and the $\mathrm{pH}$ of water in the aquifer is probably lower than the value obtained in laboratory determinations, such as the one given above

\section{SURFACE WATER}

Surface water from reservoirs on the Fred Hoskyn farm adjacent to the Rice Branch Experiment Station was used for the recharge tests. A tributary of Little La Grue Bayou receives runoff water from about a 4-square-mile area. Mr. Hoskyn pumps this water into his reservoirs, where it is stored for rice irrigation (Sniegocki and others, 1963). The results of chemical analyses of water samples collected from the Hoskyn reservoir are shown in table 1.

The surface water had a much lower dissolved-solids content than the ground water, and there seemed to be no ions in sufficient concentration to cause precipitation of sparingly soluble salts if the two waters were mixed.

Samples of the surface water, tested for bacteriological contamination by the Arkansas State Health Department, were found unsafe for drinking at the time of sampling.

The surface water had some turbidity owing to suspended material. The suspended material included iron oxide; most of the iron content reported in table 1 represented suspended rather than dissolved iron.

\section{TABLE 1.-Chemical analyses of water from Hoskyn reservoir}

[Results in parts per million except as indicated]

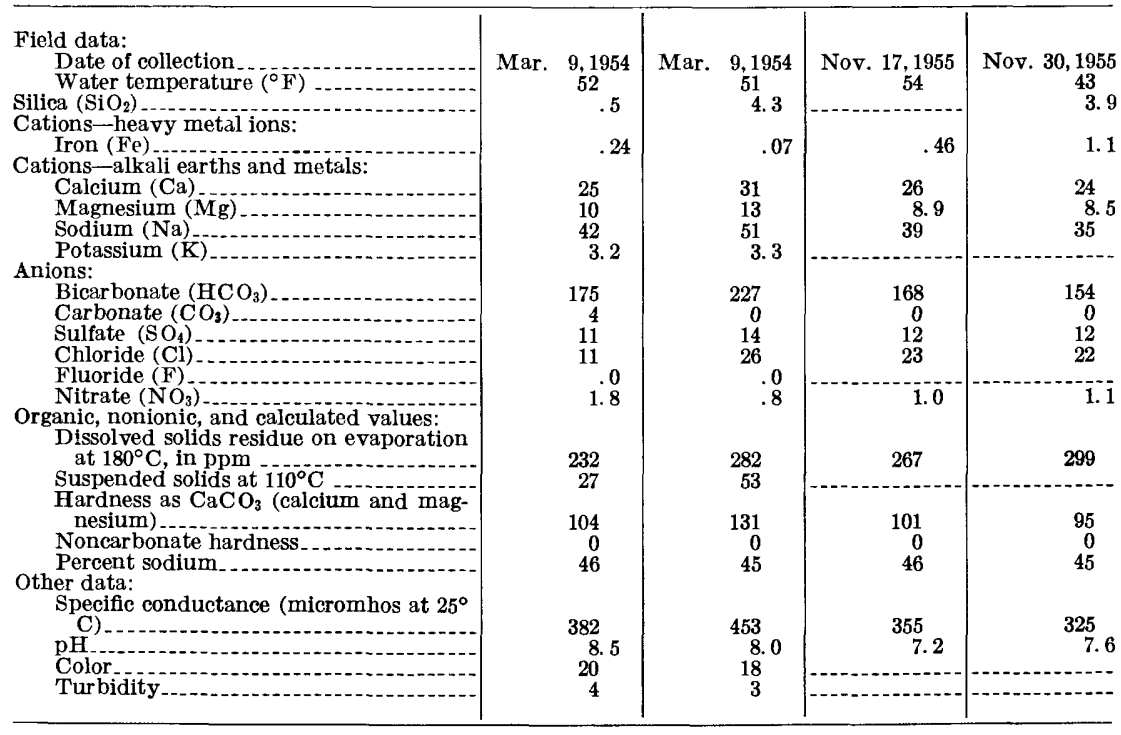




\section{GEOCHEMISTRY OF THE RECHARGE TESTS ION EXCHANGE}

A number of common rock minerals, especially the clay minerals. can adsorb cations at the surfaces of the minerals that are exposed to solutions. The kind and amount of adsorbed ions changes when the composition of the solution is changed. This process of catior exchange commonly occurs between solutes in ground water and the mineral grains in aquifers. The percent sodium in the native ground water at the recharge site averaged about 25 , and the percent sodium in the surface water averaged about 45 . Surface water injected intc the aquifer would tend to displace the native ground water and increase the proportion of monovalent cations surrounding aquifer materials, thus creating favorable conditions for ion exchange.

The physical behavior of clay particles is affected by the nature of adsorbed ions. Clays saturated with sodium may swell or be dispersed in a semicolloidal suspension. Either effect may influence the permeability of an aquifer; hence, the effect of introducing water that might cause ion exchange to take place should be considered ir recharge operations.

The upper zone of the deposits of Quaternary age at the test site contains an abundance of clay minerals, but these minerals were not in contact with the injected surface water. Each injection test generally was terminated before artesian conditions were created around the recharge well. It is unlikely, therefore, that upper-zone materials were involved in ion-exchange reactions during recharge.

The deposits of Tertiary age underlying the Quaternary deposits at the test site are composed dominantly of clayey to sandy silt. A cobble zone is at the top of the Tertiary deposits. Contact of injected surface water with Tertiary deposits at the test site was limited, and ion-exchange reactions with Tertiary clays were unlikely.

The basal zone constitutes the only part of the deposits of Quaternary age that could be involved in ion-exchange reactions. However, there is little clay mixed with the sand strata of the basal zone, and any clay dispersal from the clay lenses probably would not seriously reduce the permeability of the aquifer.

Some small changes in water composition that might have beer brought about by ion exchange resulting from the injection of surface water were observed in recharge tests 2,4 , and 20 . Test conditions and a part of the data collected during each test are shown in table 2 . The pertinent chemical-quality data collected in each test are showr in table 3 . Tests 2 and 4 were made in recharge well 1 , and test $2 C$ was made in recharge well 2 (Sniegocki and others, 1963). 
Water-level changes in the recharge well duing test 2 showed minor plugging of the well and aquifer after 40 minutes of injection. Recharge was continued until the specific capacity of the well was reduced from 25 to $7 \mathrm{gpm}$ per $\mathrm{ft}$ of drawdown. At the end of test 2, the recharge well was pumped to obtain samples of water for chemical analysis. Samples were collected also from observation wells $1 \mathrm{SW}$ and $2 \mathrm{SE}$ at the end of the test. The results of the analyses of these samples are shown in group III, table 3.

TABLE 2.-Summary of part of the data collected during recharge tests 2,4 , and 20

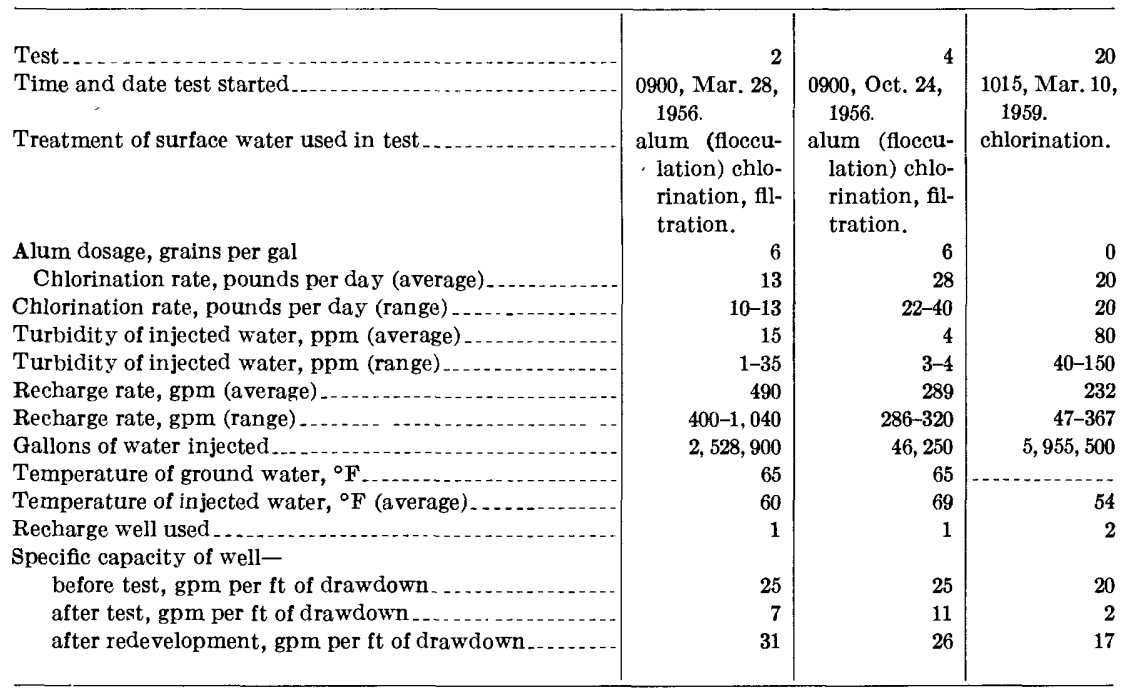

Comparison of sample 6 with sample 5 and the injected water (group II) indicates possible ion exchange, because the sodium content of the recovered water was slightly less and the calcium and magnesium content was slightly greater than in the injected water.

Although samples 5 and 6 were collected from the recharge well, they could have represented a mixture of native ground water and injected water, thereby accounting for the increase in calcium and magnesium. Chemical-quality data collected during this and other recharge studies (Sundstrom and Hood, 1952, p. 12) show that initial pumping of a recharge well produces a mixture of injected and native ground water, and a considerable quantity of water must be removed from the aquifer before undiluted recharge water can be recovered.

Furthermore, the injected water was unsaturated with respect to calcium and magnesium carbonates, and the increase in calcium and magnesium could have been caused by solution of aquifer materials. 
TABLE 3.-Chemical analyses of water samples

[Results in parts per

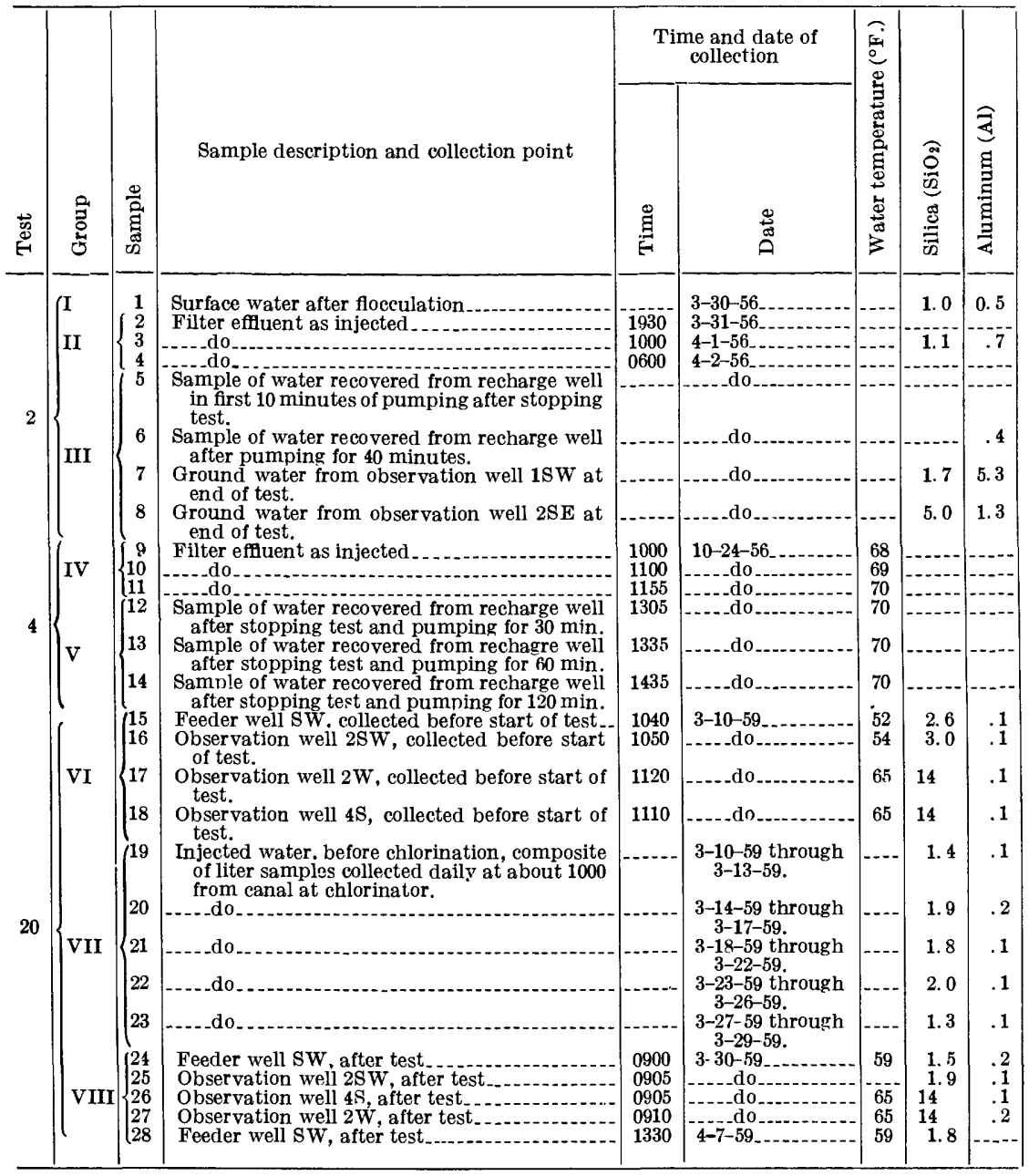


collected during recharge tests 2, 4, and 20

million except as indicated]

\begin{tabular}{|c|c|c|c|c|c|c|c|c|c|c|c|c|c|c|c|c|c|c|}
\hline \multirow[b]{2}{*}{ 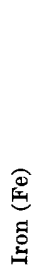 } & \multirow[b]{2}{*}{ 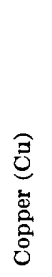 } & \multirow[b]{2}{*}{ 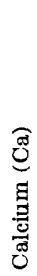 } & \multirow{2}{*}{ 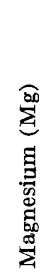 } & \multirow[b]{2}{*}{ 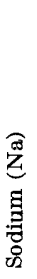 } & \multirow[b]{2}{*}{ 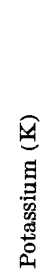 } & \multirow{2}{*}{ 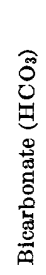 } & \multirow[b]{2}{*}{ 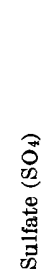 } & \multirow[b]{2}{*}{ 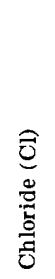 } & \multirow[b]{2}{*}{ 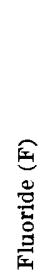 } & \multirow[b]{2}{*}{ 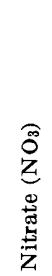 } & \multirow[b]{2}{*}{ 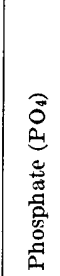 } & \multirow{2}{*}{ 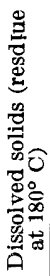 } & \multicolumn{2}{|c|}{$\begin{array}{c}\text { Hard- } \\
\text { ness as } \\
\mathrm{CaO}_{3}\end{array}$} & \multirow[b]{2}{*}{ 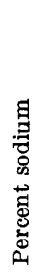 } & \multirow{2}{*}{ 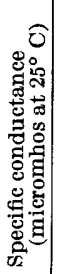 } & \multirow[b]{2}{*}{ 枯 } & \multirow[b]{2}{*}{ 농 } \\
\hline & & & & & & & & & & & & & 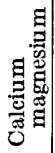 & 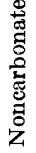 & & & & \\
\hline .00 & & 17 & 5.4 & 23 & 4. 2 & 60 & 47 & 12 & 0.3 & 1.5 & 0.21 & 152 & 65 & 15 & 42 & 245 & 7.6 & 10 \\
\hline $\begin{array}{l}.04 \\
22\end{array}$ & & 18 & & 24 & 45 & 50 & 58 & 15 & $\begin{array}{r}.0 \\
.2\end{array}$ & .9 & 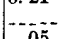 & 142 & 71 & 30 & $\begin{array}{l}42 \\
30\end{array}$ & 267 & 5 & 5 \\
\hline $\begin{array}{l}.22 \\
.04\end{array}$ & 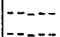 & $\begin{array}{l}19 \\
17\end{array}$ & $\begin{array}{l}5.3 \\
6.6\end{array}$ & $\begin{array}{l}22 \\
23\end{array}$ & 4.5 & $\begin{array}{l}64 \\
64\end{array}$ & $\begin{array}{l}47 \\
43\end{array}$ & $\begin{array}{l}13 \\
16\end{array}$ & $\begin{array}{r}.4 \\
.2\end{array}$ & $\begin{array}{l}1.6 \\
1.2\end{array}$ & .05 & $\begin{array}{l}171 \\
156\end{array}$ & $\begin{array}{l}69 \\
70\end{array}$ & $\begin{array}{l}17 \\
17\end{array}$ & $\begin{array}{l}39 \\
42\end{array}$ & $\begin{array}{l}249 \\
254\end{array}$ & $\begin{array}{l}7.0 \\
7.2\end{array}$ & 5 \\
\hline .02 & & 18 & 6.8 & 24 & $-1-1$ & 70 & 44 & 13 & 1. 6 & 1.3 & 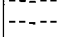 & 164 & 73 & 16 & 42 & 261 & 7. 1 & $\cdots$ \\
\hline 2.3 & & 21 & 10 & 17 & & 76 & 46 & 13 & 1.6 & 2.2 & & 156 & 94 & 31 & 28 & 277 & 6.8 & -- \\
\hline .04 & & 35 & 6.9 & 25 & 7. 0 & 130 & 49 & 13 & 1.4 & .2 & .13 & 212 & 116 & 9 & 30 & 340 & 7.0 & 22 \\
\hline .06 & & 30 & 8.5 & 26 & 3.3 & 112 & 50 & 14 & 1.1 & .6 & .25 & 215 & 110 & 18 & 33 & 325 & 7. 0 & 10 \\
\hline .00 & & 47 & 15 & 34 & & 156 & 80 & 25 & & 0 & .00 & 308 & 179 & 51 & 29 & 492 & 7.3 & 10 \\
\hline .00 & & 43 & 17 & 33 & 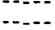 & 160 & 78 & 22 & -- & .0 & .00 & 310 & 177 & 46 & 29 & 469 & 7. & 7 \\
\hline . 100 & $\ldots$ & 45 & 16 & 34 & $\ldots$ & 159 & 81 & 22 & $-\ldots$ & .0 & $-100^{-1}$ & 302 & 178 & 48 & 29 & 468 & 7.5 & 10 \\
\hline .00 & & 44 & & 34 & $-\cdots$ & 158 & & 22 & & .0 & .02 & 306 & 176 & $4 \mathrm{~b}$ & 30 & $4 \pi$ & 1.5 & 22 \\
\hline .19 & & 46 & 17 & 34 & -..... & $\leq 62$ & 81 & 24 & 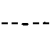 & .0 & .03 & 320 & 185 & 52 & 29 & 481 & 7.4 & 22 \\
\hline .00 & & 48 & 19 & 34 & $\cdots$ & 170 & 85 & 26 & & .0 & .13 & 328 & 198 & 58 & 27 & 497 & 7.4 & 20 \\
\hline .05 & 0.01 & 25 & 6 & 20 & 2.0 & 124 & 10 & 17 & .1 & .4 & .71 & 162 & 8 & 0 & 34 & 255 & 7. & \\
\hline .01 & .01 & 25 & & 19 & 1.4 & 128 & 12 & 14 & 2 & 1.2 & .19 & 164 & 92 & 0 & 32 & 256 & 7.5 & -..- \\
\hline 1. 6 & .00 & 99 & 30 & 48 & 3.9 & 466 & 24 & 58 & .2 & .1 & .09 & 513 & 370 & 0 & 23 & 850 & 7.8 & \\
\hline 1.4 & .00 & 91 & 29 & 43 & 3.6 & 470 & 20 & 33 & .0 & .2 & .08 & 496 & 346 & 0 & 22 & 770 & 7.8 & \\
\hline .99 & .02 & 17 & 5.0 & 19 & 2.5 & 105 & 6.2 & 8.0 & .0 & 1.4 & .14 & 123 & 63 & 0 & 39 & 183 & 7.2 & $\ldots$ \\
\hline 1.9 & .02 & 15 & 4. 6 & 19 & 2.5 & 98 & 4.4 & 11 & .1 & .9 & .02 & 120 & 56 & 0 & 41 & 180 & 7. 6 & -... \\
\hline 1.4 & .02 & 15 & 4.1 & 17 & 2.6 & 91 & 2.8 & 10 & .3 & .9 & .09 & 109 & 54 & 0 & 39 & 173 & 7.3 & 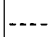 \\
\hline 1.3 & .02 & 13 & 4.1 & 14 & 2.3 & 82 & 3. 2 & 10 & .2 & .9 & .02 & 99 & 50 & 0 & 36 & 150 & 7.3 & \\
\hline 1.6 & $\therefore .07$ & 12 & 3.0 & 12 & 2.2 & 70 & 2.0 & 9 & .0 & 1. 3 & .04 & 90 & 42 & 0 & 36 & 134 & 7.4 & $\ldots$ \\
\hline 1.1 & .0 & 25 & 5. & 14 & 2. & 102 & 7. & 19 & .0 & .8 & .0 & 13 & 8 & 0 & 6 & 2 & 7. & \\
\hline .73 & & 27 & & 14 & 2. & 114 & 8.2 & 15 & .2 & 8 & 0 & & 8 & 0 & 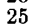 & & 7.7 & \\
\hline 2.5 & .00 & 92 & 31 & 43 & 3.7 & 475 & 21 & 33 & .0 & .2 & .0 & 502 & 357 & 0 & 21 & 78 & 7.8 & $-\cdots$ \\
\hline 1.8 & .00 & 98 & 32 & 48 & 4.0 & 465 & 25 & 61 & 1 & .2 & .06 & 543 & 376 & 0 & 22 & 865 & 7.6 & $\cdots$ \\
\hline .10 & & 28 & 6.3 & 14 & 2.8 & 116 & 8.8 & 18 & .3 & 1.2 & 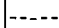 & 159 & 96 & 1 & 23 & 243 & 7.2 & 10 \\
\hline
\end{tabular}


The analyses of samples 7 and 8 , when compared with the analyses in group II (table 3), show an increase in calcium and magnesium with little change in the sodium content. Samples 7 and 8 were collected from observation wells about 25 feet from the recharge well and, presumably, represent a mixture of native ground water and injected water. Thus, the increase in calcium and magnesium in samples 7 and 8 may have resulted from the mixing of the two waters.

Severe plugging of the recharge well caused by injecting water with high turbidity masked any reduction of the specific capacity of the well that may have been caused by ion exchange. However, the chemical analyses suggest that ion-exchange effects were unimportant.

The chemical analyses of samples of the treated surface water injected during test 4 are shown in group IV, table 3. Samples of water were collected from the recharge well during a pumping period after injection ceased. The analyses of these samples (group V, table 3) indicate that the water increased slightly in calcium and magnesium, but that there was no corresponding change in sodium content while the water was in the aquifer. The changes in calcium and magnesium in the recovered water may have been the result of the mixing of the injected water with native ground water and solution of aquifer materials.

The samples in group VI (table 3) were collected from observation wells near the recharge well before beginning test 20 . Samples 15 and 16 do not represent native ground water, because all the water injected during test 19 was not withdrawn from the aquifer before beginning test 20 . The range of concentrations of ions in the water injected during test 19 is shown in a linear-pattern diagram. (See fig. 6.) A comparison of samples in group VI (table 3) with figures 3,4 , and 6 shows that the concentration of ions in the samples increases with distance from the recharge well. The samples collected from observation wells $4 \mathrm{~S}$ and $2 \mathrm{~W}$ are typical of native ground water, whereas samples from observation wells $2 \mathrm{SW}$ and FW-SW (feeder well SW) are similar to the water injected during test 19 .

The data shown in group VII (table 3) are from chemical analyses of composite samples of the water injected during test 20. Group VIII samples were collected from the same observation wells as those in group VI after test 20 was completed.

The water at wells 2 SW and FW-SW (samples 24 and 25) is similar to that injected, modified by changes that took place after injection. As in tests 2 and 4, the calcium and bicarbonate content of the injected water increased after contact with the aquifer. However, the increase in the bicarbonate content (compare samples 24 and 25 with group VII) of the injected water, as it moves to wells $2 \mathrm{SW}$ and FW-SW, is 


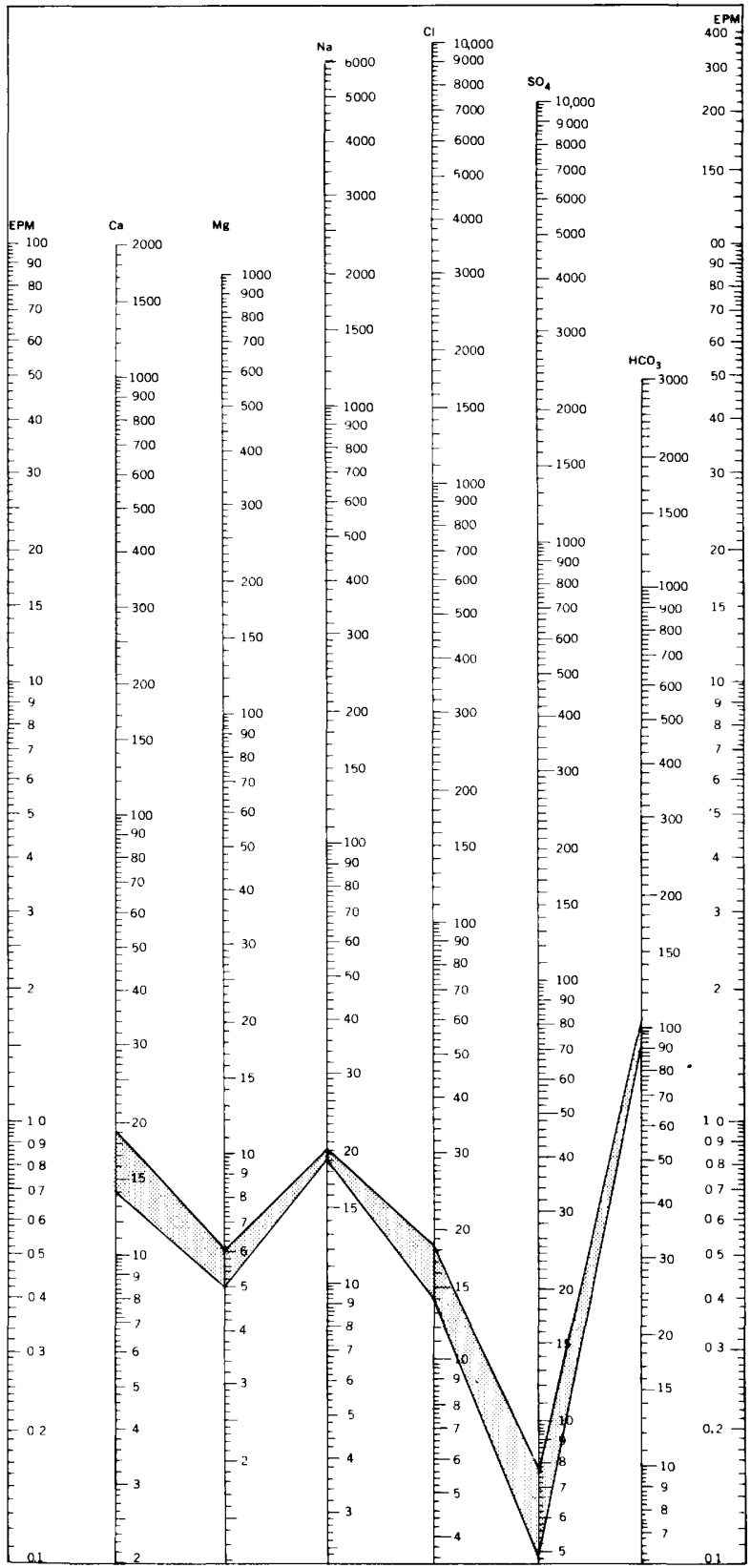

FIGURE 6.-Linear-pattern diagram showing the range of concentrations of the principal constituents of the water injected during test 19. 
not great enough to account for the total increase in calcium content. Possibly, some calcium was introduced by ion exchange.

Samples of water collected from wells FW-SW and 2SW during and after test 20 were turbid. The native ground water at the recharge site had a turbidity of 2 ppm or less. Even though group VI samples were not entirely native ground water but represented water injected during test 19 that contained as much as $72 \mathrm{ppm}$ turbidity, group VI samples were clear at the time of collection. However, after injecting water containing an average of $80 \mathrm{ppm}$ turbidity for 3 days, water collected from wells FW-SW and $2 \mathrm{SW}$ contained as much as $58 \mathrm{ppm}$ turbidity. Suspended particles were observed in samples collected from these wells throughout the remainder of the test period. No definite trend in the amount of turbidity was observed in samples collected from FW-SW as the test progressed, but a gradual increase in turbidity was observed in samples collected from well 2SW. Near the end of the test, the turbidity of samples from both wells was about $40 \mathrm{ppm}$.

Several possibilities are suggested for the source of the turbidity in these samples. These are: (1) Finely divided material might have been dislodged from the aquifer as the injected water passed through; (2) calcium carbonate, which may have been binding clay particles together, was removed by solution as injected water moved through the aquifer, thus releasing the particles; (3) clay present in the aquifer might have been deflocculated by ion exchange; and (4) the suspended material may have represented turbidity originally present in the injected water from which some of the coarser material had been removed by the aquifer close to the recharge well.

Ion-exchange effects may have contributed to plugging of the recharge well and aquifer during recharge tests. However, the data collected do not show conclusively that ion exchange took place. Probably no serious plugging effects can be attributed to ion-exchange reactions in these tests.

\section{WATER STABILITY}

In test 3 calcium chloride was added to the recnarge water before filtration so that the resultant water would have about the same relative percentage of monovalent cations as the ground water. The filter effluent, as injected, contained an average of $122 \mathrm{ppm}$ calcium. Air entrainment clogged the aquifer rapidly and severely, and test 3 had to be terminated before sufficient data could be collected to determine the effects of the addition of calcium chloride. The results of chemical analyses of water samples collected during test 3 are shown in table 4. 
No difficulty was experienced in adding calcium chloride to the recharge supply, and chemical analyses of the injected water showed that the sodium-calcium ratio had been lowered below that of the native ground water. (See group IV samples, table 4.) However, the use of calcium chloride as an additive for changing the chemical composition of water may introduce other problems.

If the solubility limit of calcium carbonate in the injected water is exceeded, calcite may precipitate and cause a reduction in aquifer permeability. A procedure suggested by Langelier (1936) and Hem $(1960,1961 \mathrm{a})$ was used for evaluating the stability of the injected water with respect to $\mathrm{pH}$ and the calcium and bicarbonate content.

An equilibrium $\mathrm{pH}$ value $\left(\mathrm{pH}_{\mathrm{eq}}\right)$ can be calculated from wateranalysis data and compared with the measured $\mathrm{pH}$ value of the water sample. If the calculated value $\left(\mathrm{pH}_{\mathrm{eq}}\right)$ exceeds the measured $\mathrm{pH}$, the water is capable of dissolving more calcium carbonate. If the measured $\mathrm{pH}$ of the water exceeds the calculated value, the water is supersaturated with respect to calcite, and calcium carbonate will precipitate. The following equilibrium can be assumed to occur between calcite in the aquifer and the water injected during recharge tests:

$$
\mathrm{CaCO}_{3}+\mathrm{H}^{+1} \rightleftarrows \mathrm{HCO}_{3}^{-1}+\mathrm{Ca}^{+2} .
$$

From the mass-action law,

$$
\frac{\left[\mathrm{HCO}_{3}^{-1}\right]\left[\mathrm{Ca}^{+2}\right]}{\mathrm{H}^{+1}}=\mathrm{K}
$$

or expressed in logarithmic form,

$$
\mathrm{pH}_{\mathrm{eq}}=-\log \frac{\left[\mathrm{Ca}^{+2}\right]\left[\mathrm{HCO}_{3}{ }^{-1}\right]}{\mathrm{K}}
$$

in which $\mathrm{K}$ represents the equilibrium constant, $0.97 \times 10^{2}$, and $\mathrm{pH}_{\text {eq }}$ represents the calculated equilibrium $\mathrm{pH}$ value. Quantities enclosed in brackets, [ ], represent activities or thermodynamic concentrations in moles per liter. Water analyses are reported in stoichiometric concentrations, which must be converted to thermodynamic concentrations before values can be placed in the foregoing equation. For waters in the concentration ranges in this study the activities can be calculated from the Debye-Hückel equation and the ionic strength of the solution. Graphical aids for computing ionic strength have been published by Hem (1961a). Concentrations in parts per million can be converted to moles per liter by standard chemical calculations. 
TABLE 4.-Chemical analyses, in parts per million, of

\begin{tabular}{|c|c|c|c|c|c|c|c|c|}
\hline \multirow{2}{*}{ Group } & \multirow{2}{*}{$\begin{array}{l}\text { Sam- } \\
\text { ple }\end{array}$} & \multirow{2}{*}{$\begin{array}{l}\text { Sample desrription and } \\
\text { collection point }\end{array}$} & \multicolumn{2}{|c|}{$\begin{array}{l}\text { Time and date } \\
\text { of collection }\end{array}$} & \multirow{2}{*}{$\begin{array}{l}\text { Tem- } \\
\text { pera- } \\
\text { trre } \\
\left({ }^{\circ} \mathrm{F}\right)\end{array}$} & \multirow{2}{*}{$\begin{array}{l}\text { Iron } \\
(\mathrm{Fe})\end{array}$} & \multirow{2}{*}{$\begin{array}{l}\text { Calci- } \\
\text { um } \\
\text { (Ca) }\end{array}$} & \multirow{2}{*}{$\begin{array}{l}\text { Mag- } \\
\text { ne- } \\
\text { sinim } \\
(\mathrm{Mg})\end{array}$} \\
\hline & & & Time & Date & & & & \\
\hline I & 1 & $\begin{array}{l}\text { Ground water, from discharge pipe of } \\
\text { recharge well before test. }\end{array}$ & & $9-26-56$ & 66 & 0.48 & 87 & 31 \\
\hline II & 2 & $\begin{array}{l}\text { Surface water, untreated, from supply } \\
\text { canal. }\end{array}$ & & $9-26-56$ & 81 & .37 & 26 & 20 \\
\hline \multirow[t]{2}{*}{ III } & 3 & $\begin{array}{l}\text { Surface water, after flocculation and } \\
\text { settling, at chlorinator. }\end{array}$ & 1230 & $10-10-56$ & & .01 & 40 & 13 \\
\hline & 4 & Filter effuent as injected & 1030 & $10-10-56$ & 65 & .05 & 123 & 16 \\
\hline IV & $\begin{array}{l}5 \\
6\end{array}$ & $-\mathrm{d}_{\mathrm{d}} \mathrm{d} \mathrm{o}_{\mathrm{n}}$ & $\begin{array}{l}1111 \\
1211\end{array}$ & $\begin{array}{l}10-10-56 \\
10-10-56\end{array}$ & & $\begin{array}{l}.01 \\
.03\end{array}$ & $\begin{array}{l}131 \\
112\end{array}$ & $\begin{array}{l}20 \\
15\end{array}$ \\
\hline \multirow[t]{2}{*}{$\mathrm{V}$} & $\begin{array}{l}7 \\
8\end{array}$ & $\begin{array}{l}\text { Feeder well SW drring test } \\
\text { Feederwell } \mathrm{SW} \text { 5minafter topping test }\end{array}$ & $\begin{array}{l}1141 \\
1230\end{array}$ & $\begin{array}{l}10-10-56 \\
10-10-56\end{array}$ & 65 & .00 & 123 & 18 \\
\hline & 9 & $\begin{array}{l}\text { Sample of water recovered from re- } \\
\text { charge well after stopping test at } \\
1225 \text {, and collecting sample at time } \\
\text { indicated. }\end{array}$ & 1240 & $10-10-56$ & & .39 & 112 & 15 \\
\hline \multirow[t]{5}{*}{ VI } & 10 & - do & 1245 & $10-10-56$ & & .08 & 110 & 18 \\
\hline & $\begin{array}{l}11 \\
12\end{array}$ & - do & $\begin{array}{l}1250 \\
1255\end{array}$ & $\begin{array}{l}10-10-56 \\
10-10-56\end{array}$ & & $\begin{array}{l}.07 \\
.08\end{array}$ & $\begin{array}{l}112 \\
117\end{array}$ & $\begin{array}{l}15 \\
16\end{array}$ \\
\hline & 13 & do & 1325 & $10-10-56$ & & .05 & 116 & 20 \\
\hline & l 14 & do & 1355 & $10-10-56$ & & .08 & 121 & 23 \\
\hline & $(15$ a & $\begin{array}{l}\text { Sample of water recovered from re- } \\
\text { charge well after adding sodium hex- } \\
\text { ametaphosphate to well and pump- } \\
\text { ing for } 30 \text { min. }\end{array}$ & & $10-11-56$ & & .00 & 105 & 25 \\
\hline \multirow{2}{*}{ VII } & 16 & $\begin{array}{l}\text { Sample of water recovered from re- } \\
\text { charge well after pumping } 45 \mathrm{~min} \text {. }\end{array}$ & & & & .07 & 94 & 31 \\
\hline & $(17 \mathrm{~b}$ & $\begin{array}{l}\text { Sample of water recovered from re- } \\
\text { charge well after acidizing well and } \\
\text { pumping for } 30 \mathrm{~min} \text {. }\end{array}$ & & $10-12-56$ & & 3.5 & 138 & 40 \\
\hline \multirow[t]{2}{*}{ VIII } & 18 & $\begin{array}{l}\text { Sample of water recovered from re- } \\
\text { charge well after acidizing well and } \\
\text { pumping for } 60 \mathrm{~min}\end{array}$ & & $10-12-56$ & & 1.3 & 104 & 43 \\
\hline & 19 & $\begin{array}{l}\text { Sample of water recovered from re- } \\
\text { charge well after acidizing well and } \\
\text { pumping for } 100 \mathrm{~min} \text {. }\end{array}$ & & $10-12-56$ & & 2.5 & 94 & 39 \\
\hline
\end{tabular}

a Sodium hexametaphosphate added to recharge well on Oct. 10, 1956, after collecting group VI samples, redevelopment chemicals left in well overnight prior to collecting group VII samples.

An equilibrium $\mathrm{pH}$ value $\left(\mathrm{pH}_{\mathrm{eq}}\right)$ was calculated for sample 5 , table 4 , using the methods outlined. Sample 5 was selected for the calculation because it contained more calcium than other samples in group IV. Therefore, if the equilibrium $\mathrm{pH}$ value $\left(\mathrm{pH}_{\mathrm{eq}}\right)$ of sample 5 indicated that the injected water was stable, it was safe to assume that all the water injected during test 3 was stable.

The ionic strength of sample 5 was computed to be 0.015 (Hem, $1961 \mathrm{a}, \mathrm{pl}$. 1). The activity coefficient calculated from the DebyeHückel equation for calcium at this ionic strength is 0.63 , and for bicarbonate it is 0.88 .

Upon converting parts per million concentrations to moles per liter and substituting appropriate values into the equation,

$$
\mathrm{pH}_{\mathrm{eq}}=-\log \frac{\left[\left(3.27 \times 10^{-3}\right)(0.63)\right]\left[\left(2.13 \times 10^{-3}\right)(0.88)\right]}{0.97 \times 10^{2}}=7.4
$$


water samples collected during recharge test 3

\begin{tabular}{|c|c|c|c|c|c|c|c|c|c|c|c|c|}
\hline \multirow{2}{*}{$\begin{array}{l}\text { Sodi- } \\
\text { um } \\
\text { (Na) }\end{array}$} & \multirow{2}{*}{$\begin{array}{c}\text { Bicar- } \\
\text { bonate } \\
\left(\mathrm{HCO}_{3}\right)\end{array}$} & \multirow{2}{*}{$\begin{array}{c}\text { Sul- } \\
\text { fate } \\
\left(\mathrm{SO}_{4}\right)\end{array}$} & \multirow{2}{*}{$\begin{array}{l}\text { Chlo- } \\
\text { ride } \\
\text { (Cl) }\end{array}$} & \multirow{2}{*}{$\begin{array}{c}\mathrm{Ni}- \\
\text { trate } \\
\left(\mathrm{NO}_{3}\right)\end{array}$} & \multirow{2}{*}{$\begin{array}{l}\text { Phos- } \\
\text { phate } \\
\left(\mathrm{PO}_{4}\right)\end{array}$} & \multirow{2}{*}{$\begin{array}{l}\text { Dis- } \\
\text { solved } \\
\text { solids } \\
\text { (residue } \\
\text { at, } 180 \\
\left.{ }^{\circ} \mathrm{C}\right)\end{array}$} & \multicolumn{2}{|c|}{$\underset{\mathrm{CaCO}_{3}}{\text { Hardness as }}$} & \multirow{2}{*}{$\begin{array}{c}\text { Percent } \\
\text { Sodi- } \\
\text { um }\end{array}$} & \multirow{2}{*}{$\begin{array}{c}\text { Speciflc } \\
\text { con- } \\
\text { duct- } \\
\text { ance } \\
\text { (micro- } \\
\text { mhos } \\
\text { at. } 25 \\
{ }^{\circ} \mathrm{C} \text { ) }\end{array}$} & \multirow{2}{*}{$\mathrm{pH}$} & \multirow{2}{*}{ Color } \\
\hline & & & & & & & $\begin{array}{c}\text { Calci- } \\
\text { um, } \\
\text { mag- } \\
\text { nesium }\end{array}$ & $\begin{array}{c}\text { Non- } \\
\text { car- } \\
\text { bonate }\end{array}$ & & & & \\
\hline 47 & 457 & 20 & 30 & 0.2 & & 465 & 344 & 0 & 23 & 758 & 7.3 & 5 \\
\hline 50 & 237 & 21 & 28 & .0 & & 306 & 147 & 0 & 42 & 482 & 8.0 & 22 \\
\hline 34 & 142 & 86 & 17 & .2 & & 291 & 153 & 37 & 33 & 429 & 7.9 & 15 \\
\hline 38 & 130 & 84 & 175 & 9 & & 748 & 373 & 266 & 18 & 916 & 7. 6 & 10 \\
\hline 38 & 130 & 87 & 198 & 1. 3 & -..... & 825 & 409 & 302 & 17 & 992 & 7.4 & 10 \\
\hline 37 & 131 & 85 & 150 & .2 & - - & 664 & 341 & 234 & 19 & 843 & 7.5 & 15 \\
\hline 37 & 137 & 86 & 172 & 1.6 & & 740 & 381 & 268 & 17 & 921 & 7.5 & 10 \\
\hline $\begin{array}{l}37 \\
37\end{array}$ & 136 & 85 & 150 & .2 & - & 678 & 343 & 232 & 19 & 845 & 7.5 & 15 \\
\hline 37 & 134 & 86 & 150 & .2 & 0.22 & 569 & 341 & 231 & 19 & 848 & 7.6 & 10 \\
\hline 38 & 136 & 83 & 155 & .9 & .17 & 569 & 348 & 237 & 19 & 851 & 7. 6 & 10 \\
\hline 38 & 136 & 86 & 152 & 1.6 & .20 & 595 & 341 & 230 & 19 & 857 & 7.7 & 17 \\
\hline 38 & 134 & 87 & 158 & 1.4 & .17 & 610 & 358 & 248 & 19 & 879 & 7.8 & 10 \\
\hline 38 & 138 & 88 & 162 & .8 & .17 & 648 & 372 & 258 & 18 & 900 & 7.8 & 10 \\
\hline 38 & 140 & 85 & 185 & 1.7 & 14 & 691 & 396 & 282 & 17 & 958 & 7.8 & 10 \\
\hline & 478 & 17 & 32 & .2 & .93 & 489 & 365 & 0 & 23 & 798 & 7.6 & 10 \\
\hline 50 & 475 & 20 & 30 & .2 & .73 & 477 & 362 & 0 & 23 & 793 & 7.5 & 7 \\
\hline 49 & 410 & 25 & 190 & 1.3 &..-- & 760 & 509 & 173 & 17 & 1210 & 7.2 & 10 \\
\hline 50 & 443 & 26 & 108 & .2 & & 604 & 436 & 74 & 20 & 992 & 7.2 & 10 \\
\hline 49 & 456 & 25 & 66 & .2 & & 493 & 395 & 22 & 21 & 885 & 7.3 & 10 \\
\hline
\end{tabular}

b Inhibited $\mathrm{HCl}$ added to recharge well on Oct. 11, 1956, after collecting group VII samples, acid left in well overnight prior to collecting group VIII sampels.

The $\mathrm{pH}$ of sample 5, measured at the time of collection, was 7.4. The injected water was stable with respect to calcite because the measured and calculated $\mathrm{pH}$ values were equal. However, if additional calcium chloride had been added to the injected water, ionic concentrations might have been changed sufficiently to cause calcium carbonate to precipitate and, subsequently, plug the well and aquifer.

Equilibrium $\mathrm{pH}$ values for systems containing calcite can be estimated from graphs published by Hen (1961a, figs. 1 and 2, p. c 5, c 15) using activities of calcium and bicarbonate ions in parts per million.

The process by which natural water acquires or relinquishes solutes in relation to their ionic activity should be considered when attempting artificial recharge through wells. Successful recharge cannot be accomplished for any extended period if the waters involved are unstable and cause sparingly soluble salts to precipitate and clog the aquifer. 
The $\mathrm{pH}$ of a solution is a measure of the effective hydrogen-ion concentration and represents ionic activity rather than a stoichiometric relationship. Carbon dioxide in solution as undissociated carbonic acid, along with dissociated bicarbonate and carbonate ions, constitutes a buffered solution, which controls the $\mathrm{pH}$ of most natural waters. The carbon dioxide-bicarbonate system is not stable if the system is subjected to an environment where carbon dioxide may be added or may escape from solution.

The obvious source of carbon dioxide in most natural waters is the atmosphere, which contains about 0.03 percent carbon dioxide by volume. Air in soil generally contains 10 to 100 times as much carbon dioxide as the atmosphere. Therefore, the unwatered zone of the deposits of Quaternary age at the recharge site probably contains air with a relatively high percentage of carbon dioxide. The ground water is not directly exposed to the atmosphere because of the capping clay layer. As a consequence of the stability of the ground-water environment, the carbonic acid-bicarbonate-carbonate balance in the ground water in the aquifer will remain constant, as well as the $\mathrm{pH}$.

When the ground water is exposed to the atmosphere, a part of the carbon dioxide may escape and the $\mathrm{pH}$ will increase. This phenomenon is common; increases of as much as $2.0 \mathrm{pH}$ units (from 6.5 to 8.5) have been noted in water from deposits of Quaternary age in Arkansas. As the $\mathrm{pH}$ rises, calcium carbonate will precipitate. Recharge of surface water could disturb the carbonic acid-bicarbonate-carbonate balance of the native ground water and cause precipitation of calcium carbonate and a subsequent reduction in aquifer permeability.

The native ground water contains large amounts of calcuim and bicarbonate. Computations show that the ground water at the recharge site in its native environment is saturated with respect to calcite. The available carbon dioxide supply, with which the system is in equilibrium in the aquifer, is much greater than could be supplied from the atmosphere. The injection supply generally is not saturated with respect to calcium carbonate and should, therefore, form a stable solution when mixed with the ground water upon recharge.

However, long-term recharge may alter the chemical balance of water in the aquifer. The analyses of injected and recovered water show that the water tends to pick up carbon dioxide as it moves through the aquifer. As an example, the recharge water in one test run contained about $4 \mathrm{ppm}$ carbon dioxide at the time of injection. A sample of the injected water, recovered from the aquifer 5 days after injection, contained about $11 \mathrm{ppm}$ carbon dioxide If cyclic recharge (injection and pumping) is continued, the available supply of carbon dioxide in the aquifer surrounding the recharge well may be depleted. Upon reentry of native ground water into a zone depleted 
of carbon dioxide, the native ground water would readjust to a lower carbon dioxide environment, causing the deposition of calcium carbonate. The injection periods were not long enough to determine whether any plugging was caused by precipitated calcium carbonate. Also, in most tests, rapid and early plugging caused by air entrainment and sediment masked plugging from other factors. However, the increase in carbon dioxide and calcium content of recovered injected water is evidence of a change in chemical balance of the solution and environment. The change might create favorable conditions for precipitation of carbonate from the native ground water.

\section{FERROUS-FERRIC IRON RELATIONSHIPS}

Published literature on artificial recharge largely disregards the chemistry of iron in natural waters and considers only the short-term plugging effects from iron that occur rapidly and, hence, are more apparent. The application of stability-field diagrams for dissolved iron (Hem, 1960, 1961b, and Hem and Cropper, 1959) to chemicalquality data collected in this study indicates a potential plugging by iron that might not be apparent until the recharge system had been operated several months.

The redox potential $(\mathrm{Eh})$ and $\mathrm{pH}$ of native ground water and surface water similar to that injected during test 3 (table 4) were measured in the field laboratory. These values are shown on a stability-field diagram (fig. 7). The native ground water has an $\mathrm{Eh}$ and $\mathrm{pH}$ that would permit ferrous iron to remain in solution. The surface water, however, has an $\mathrm{Eh}$ and $\mathrm{pH}$ at which ferrous iron would be almost completely oxidixed and precipitated as ferric hydroxide.

During recharge, the surface water would move outward from the recharge well and some iron would be precipitated at the point where the introduced water contacted the native ground water. This point of contact would represent a front that would become less well defined as injection continued and water moved away from the recharge well. Pumping the recharge well after injection would move native ground water back through the zone of the aquifer that had been occupied by the injected water, causing a reversal of the oxidation potential. Part of the precipitated iron would be flushed out and the reestablishment of reducing conditions would tend to dissolve the remaining iron precipitate. The iron analyses of samples in groups 1 and 4 and groups 6,7 , and 8 (table 4 ) suggest that the foregoing changes in iron content of the injected and native ground water may have occurred during test 3 . Some of the backflushed water contained a higher concentration of iron than the native ground water or injected water, perhaps indicating flushing and reduction of the iron. 


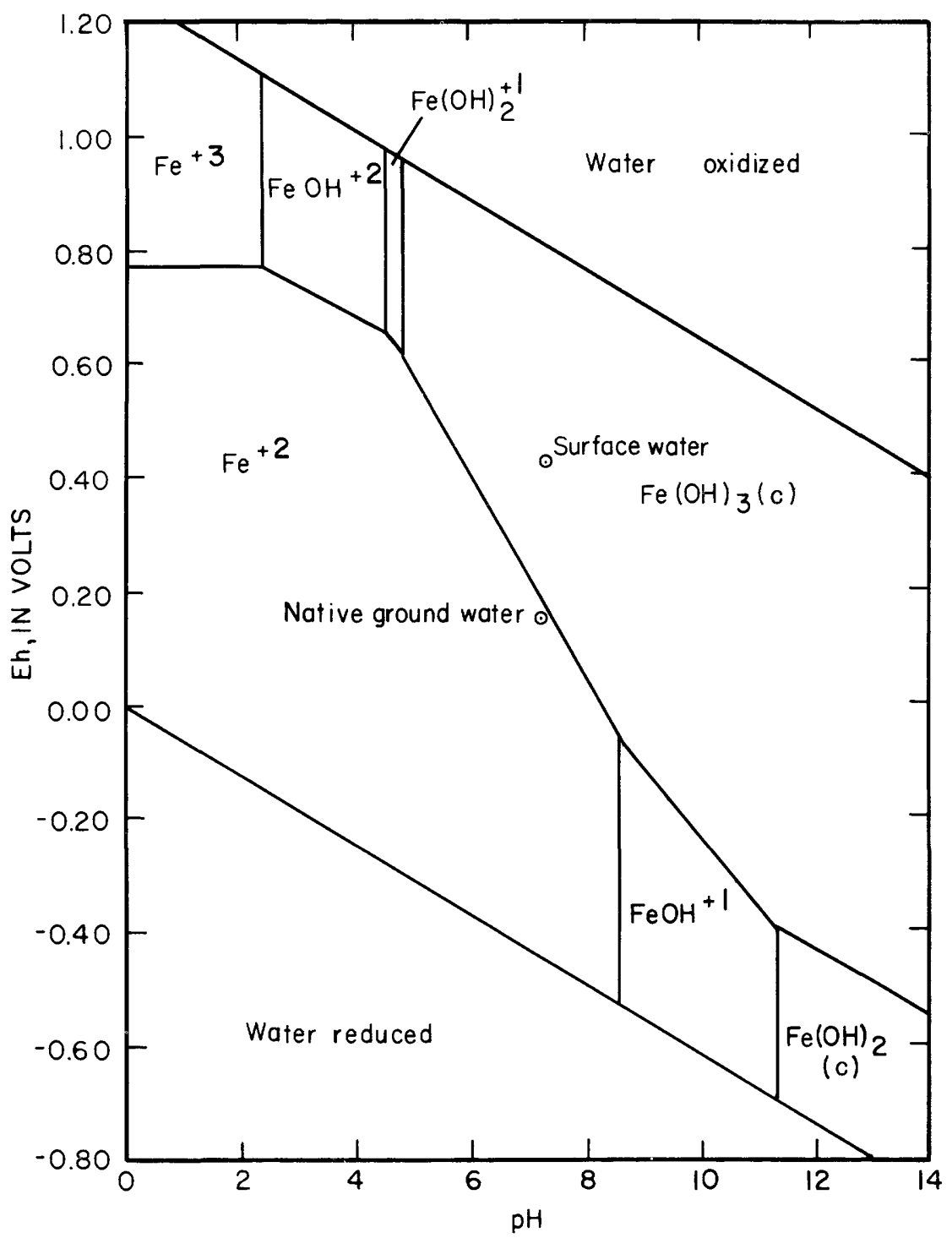

F1GURE 7.-Stability-field diagram for aqueous ferric-ferrous system in which the dissolved-iron activity is $0.01 \mathrm{ppm}$.

As long as the reaction is reversible, precipitated iron could be easily removed by merely pumping the recharge well. During pumping, the restablishment of reducing conditions in the aquifer would tend to cause resolution of precipitated iron and might cause a front of fairly high iron concentration which, however, would lag 
somewhat behind the front of the advancing native ground water. All the injected water as well as some of the native ground water would have to be removed from the aquifer to ensure complete removal of the lagging zone of water containing a high concentration of iron. Furthermore, mixing of the two waters occurs during pumping, and two to three times the injected quantity would have to be removed in order to reclaim all the injected water. Unless pumping could be prolonged at a time when the water has economic value, such as during an irrigation season, no storage gain could be made in the ratio of injected to backflushed water. As a consequence of limiting backflushing of the recharge well, a small amount of precipitated iron and the lagging front of water containing a high concentration of dissolved iron would remain in the aquifer between injection periods. The plugging effect would be negligible at first, but longterm recharge and an accumulation of precipitated iron could cause an increasing and eventually severe reduction of aquifer permeability. This type of plugging would occur most likely at a considerable distance from the recharge well and be more difficult to remove during redevelopment operations.

Many recharge tests made during this investigation were terminated after a short period of operation because of rapid and severe plugging caused by factors other than iron precipitated in the aquifer. Because recharge periods were short, few data were collected that substantiated plugging caused by the mixing of oxidizing and reducing waters. However, water recovered from the recharge well after nearly all tests contained higher concentrations of iron than the injected or native ground water. The concentration of iron occasionally was in excess of $9 \mathrm{ppm}$. This could have been the result of the mixing of reducing and oxidizing waters in the aquifer.

The surface water used for injection contained considerable dissolved oxygen, enough to precipitate iron from at least 10 times its volume of the native ground water. The residual free chlorine in the injected water also is capable of oxidizing iron.

Recharge test 1, which utilized ground water as the injection supply, was made to check hydraulic coefficients of the aquifer determined by pumping tests, to develop operational techniques for later tests, and to learn whether artificial recharge through a well could be successfully accomplished at any practical rate under favorable conditions. As shown by the following table, the iron content of the ground water used for injection was relatively high, and if the iron precipitated, it could clog the recharge well and aquifer. 
Iron analyses of ground water

[Complete analyses given in table 4, East well, 3S-4W 3dda 1 , Sniegocki, 1963]

\begin{tabular}{l|c|c|c|c|c|c|c|c|c}
\hline & \multicolumn{10}{c}{ Date of collection } \\
\cline { 2 - 6 } & Aug. 13 & June 3 & July 14 & July 21 & July 28 & Aug. 6 & Aug. 28 & Sept. 1 & Sept. 14 \\
\hline Iron (ppm) - & 1.4 & 1.8 & 0.90 & 1.5 & 7.4 & 0.54 & 2.3 & 0.83 & 0.60 \\
\hline
\end{tabular}

The aluminum irrigation pipe used to bring the ground water from its source (an irrigation well a quarter of a mile away) to the recharge well maintained an airtight seal at the pipe couplings as long as water pressure was maintained by pumping and recharging at $500 \mathrm{gpm}$. Intentional lowering of the pumping and injection rate to $300 \mathrm{gpm}$ allowed aeration of the water at each pipe coupling as air entered the system. Although air entrainment was the major cause of clogging the well and aquifer during test 1 , a significant amount of clogging probably was caused by iron precipitated from the injection supply. Water recovered from the recharge well after injection test 1 appeared very red and turbid because of the high content of precipitated iron.

\section{WATER TREATMENT}

Water-treatment equipment and procedures used during this investigation are described in another report in this series (Sniegocki and others, 1963). However, in evaluating changes in chemical quality of the injection supply, it is important to consider the watertreatment procedures, including the kinds and amounts of flocculating and chlorinating agents and the conditions of their application.

Commercial-grade alum was used as the coagulant in all recharge tests involving pretreatment of surface water. Dosage ranged from about 2 to 12 grains per gallon. Chemical treatment by the addition of alum reduced the turbidity of the water from 150 to $4 \mathrm{ppm}$.

Pretreated water left in the settling canal after recharge test 4 became turbid owing to wind action, rain, and levee bankwash, and fish, frog, and turtle movement. Rather than empty the entire canal and pretreat a completely new supply of water by use of the dry chemical feeder, pulverized alum was hand spread over the surface of the water in the canal before test 5 was begun. The approximate dosage was 12 grains per gallon of water. The turbidity of the water was lowered from about 40 tc $3 \mathrm{ppm}$. However, the additional alum 
added to the water by hand spreading caused an increase in the sulfate content and a decrease in the bicarbonate content (table 5).

Presumably, the changes in chemical quality of the water were similar to the following equation related to coagulation with alum and natural alkalinity.

$$
\mathrm{Al}_{2}\left(\mathrm{SO}_{4}\right)_{3} \cdot 18 \mathrm{H}_{2} \mathrm{O}+3 \mathrm{Ca}\left(\mathrm{HCO}_{3}\right)_{2} \rightarrow 2 \mathrm{Al}(\mathrm{OH})_{3}+3 \mathrm{CaSO}_{4}+18 \mathrm{H}_{2} \mathrm{O}+6 \mathrm{CO}_{2} \text {. }
$$

Thus, the sulfate content of the water was increased by an additional dosage of alum, and subsequent precipitation of aluminum hydroxide caused a decrease in the bicarbonate content. The close relation between $\mathrm{pH}$, alkalinity, and the coagulation reaction controls the amount of $\mathrm{Al}^{+3}$ that can be present in solution. Thus, although the water as hand treated may have been stable with respect to its alumnium content in the canal, injection into the aquifer and mixing with the native ground water could have altered the $\mathrm{pH}$ and alkalinity of the solutions, causing postflocculation of residual aluminum.

Aluminum cations in solution hydrolyze strongly as follows (Hem, 1959, p. 69):

$$
\mathrm{Al}^{+3}+3 \mathrm{H}_{2} \mathrm{O} \rightarrow \mathrm{Al}(\mathrm{OH})_{3}+3 \mathrm{H}^{+1} .
$$

The aluminum hydroxide is slightly dissociated and nearly insoluble at near-neutral $\mathrm{pH}$; hence, the $\mathrm{pH}$ of a solution containing more than traces of $\mathrm{Al}^{+3}$ ions must be considerably below 7 . Aluminum may, however, also be present in anionic form and in this form is more soluble at $\mathrm{pH} 7$.

Samples were collected from observation wells about 20 feet from the recharge well during and after recharge test 2 . The samples contained about $1 \mathrm{ppm}$ more aluminum than either the native ground water or the water injected during the test. Two postulations are given to account for the foregoing. Postflocculation may have occurred in the aquifer, the floc accumulating near the sampling wells. The wells were far enough from the point of injection so that the velocity of water movement through the aquifer was very slow, allowing maximum filtering efficiency of the aquifer and complete settling of floc. The water samples from the wells may have contained finely dispersed aluminum hydroxide, accounting for the high aluminum content of the water samples. In addition, the recharge supply may have contained finely dispersed aluminum hydroxide while it was injected. 
TABLE 5.-Chemical analyses of samples of the surface water used for injection during recharge tests 4 and 5

[Results in ppm, except as indicated]

\begin{tabular}{|c|c|c|}
\hline & \multicolumn{2}{|c|}{ Alum pretreatment- } \\
\hline & $\begin{array}{l}\text { With chemical } \\
\text { feeder, test } 4\end{array}$ & $\begin{array}{c}\text { By handspreading, } \\
\text { test } 5\end{array}$ \\
\hline \multicolumn{3}{|l|}{ Field data: } \\
\hline Date of collection & Oct. 24,1956 & Nov. 7,1956 \\
\hline Water temperature $\left({ }^{\circ} \mathbf{F}\right)$ & 67 & 64 \\
\hline \multicolumn{3}{|l|}{ Cations-heavy metal ions: } \\
\hline Iron $(\mathrm{Fe})$ & .00 & .12 \\
\hline \multicolumn{3}{|l|}{ Cations-alkali earths and metals: } \\
\hline Calcium $(\mathrm{Ca})$ & 47 & 44 \\
\hline Magnesium $(\mathrm{Mg})$ & 15 & 14 \\
\hline Sodium $(\mathrm{Na})$ & 34 & 30 \\
\hline \multicolumn{3}{|l|}{ Anions: } \\
\hline Bicarbonate $\left(\mathrm{HCO}_{3}\right)_{2}$ & 156 & 112 \\
\hline Sulfate $\left(\mathrm{SO}_{4}\right)$ & 80 & 116 \\
\hline Chloride $(\mathrm{Cl})$ & 25 & 16 \\
\hline Nitrate & .0 & .0 \\
\hline Phosphate $\left(\mathrm{PO}_{4}\right)$ & .00 & - \\
\hline \multicolumn{3}{|l|}{ Organic, nonionic, and calculated values: } \\
\hline $\begin{array}{l}\text { Dissolved solids, residue on evaporation at } \\
180^{\circ} \mathrm{C}\end{array}$ & 308 & 295 \\
\hline Hardness as $\mathrm{CaCO}_{3}$ (calcium and magnesium)- & 179 & 168 \\
\hline Noncarbonate hardness & 51 & 76 \\
\hline Percent sodium & 29 & 28 \\
\hline \multicolumn{3}{|l|}{ Other data: } \\
\hline Specific conductance (micromhos at $25^{\circ} \mathrm{C}$ ) $\ldots$ & 492 & 464 \\
\hline $\mathrm{pH}$ & 7. 3 & 7. 2 \\
\hline Color & 10 & 7 \\
\hline Turbidity & 3 & 3 \\
\hline
\end{tabular}

As shown in the following table, the abnormally high aluminum content of water samples collected from the aquifer after recharge was observed only in one test. The alum dosage in test 2 was about 6 grains per gallon and not significantly higher than dosage applied in other tests. Therefore, it cannot be conclusively established that the high recovery of aluminum after test 2 was the result of the addition of more alum to the injected water than in other tests. The lack of consistency in the data shown in the table suggests that no serious 
clogging problems were caused by using alum as a coagulant. However, overdosage in alum treatment should be avoided because postflocculation and subsequent clogging could result.

\begin{tabular}{|c|c|c|c|}
\hline \multirow{2}{*}{ Test } & \multicolumn{3}{|c|}{ Aluminum content (ppm) of sample- } \\
\hline & $\begin{array}{c}\text { From aquifer } \\
\text { before test }\end{array}$ & $\begin{array}{l}\text { Of injected } \\
\text { water }\end{array}$ & $\begin{array}{l}\text { Recovered } \\
\text { from aquifer } \\
\text { after test }\end{array}$ \\
\hline 2. & 0. 8 & 0.5 & 1. 8 \\
\hline 12 & .62 & .61 & .82 \\
\hline 13 & .82 & .53 & .59 \\
\hline 14 & .33 & .19 & 26 \\
\hline 18 & .3 & .1 & 0 \\
\hline 19 & .1 & .0 & 0 \\
\hline 20 & .1 & .1 & .2 \\
\hline
\end{tabular}

Experiments were made with other coagulating agents to determine if a floc could be formed that would be less subject to dispersal after having once settled. Separan was selected for testing because it would not be involved in chemical reactions with the water, and the floc formed seemed to be heavy and cohesive. Separan is a trade name used by the Dow Chemical Co. for a high-molecular-weight polyacrylamide, which is described as anionic, synthetic, water soluble, and suitable for flocculation when used in dilute aqueous solutions of 0.05 percent or less.

Separan AP30, NP10, and NP20 were tested in the laboratory under closely controlled conditions, but results were unsatisfactory as the reduction in turbidity was slight. Field tests were made with the assistance of W. C. Blackney, Jr., Dow Chemical Co., on $500 \mathrm{ml}$ (milliliter) surface-water samples at the recharge site. The turbidity of the water was $30 \mathrm{ppm}$. Samples treated with solutions of alum and Separan AP30, NP10, and NP20 were stirred rapidly for 30 seconds and at 35 to $40 \mathrm{rpm}$ (revolutions per minute) for about 3 minutes. The results of these tests are shown in the following table (M. E. Schroeder, written communication, 1961). 


\begin{tabular}{|c|c|c|}
\hline Sample & Coagulant used & Results \\
\hline $1 \ldots$ & Alum, 4 grains per gallon & Good floc that settled rapidly \\
\hline 2 & NP20, 1.5 ppm. & Almost no noticeable effect. \\
\hline $3 \ldots$ & $\begin{array}{l}\text { NP20, } 1.5 \text { ppm plus } 10 \text { ppm } \\
\text { lime. }\end{array}$ & Small floc that did not settle. \\
\hline $4 \ldots$ & Alum, 4 grains per gal $\ldots \ldots$ & $\begin{array}{l}\text { Good floc that settled rapidly, } \\
\text { turbidity of supernatant liquid, } \\
1 \text { ppm. }\end{array}$ \\
\hline $5 \ldots \ldots$ & $\begin{array}{l}\text { AP30, } 0.5 \text { ppm plus } 2 \text { grains } \\
\text { per gal of alum. }\end{array}$ & $\begin{array}{l}\text { Good floc that settled rapidly but } \\
\text { supernatant liquid had milky } \\
\text { appearance and turbidity of } 7 \\
\text { ppm. }\end{array}$ \\
\hline $6 \ldots \ldots$ & $\begin{array}{l}\text { AP30, } 0.5 \text { ppm plus } 1 \text { grain per } \\
\text { gal of alum. }\end{array}$ & $\begin{array}{l}\text { Small floc that settled slowly } \\
\text { leaving milky looking super- } \\
\text { natant liquid with turbidity of } \\
20 \mathrm{ppm} \text {. }\end{array}$ \\
\hline & $\begin{array}{l}\text { AP30, } 1 \text { ppm plus } 1 \text { grain per } \\
\text { gal of alum. }\end{array}$ & $\begin{array}{l}\text { No noticeable effect, turbidity of } \\
\text { solution } 30 \mathrm{ppm} \text {. }\end{array}$ \\
\hline 8 & $\begin{array}{l}\text { NP10, } 0.5 \text { ppm plus } 1 \text { grain } \\
\text { per gal of alum. }\end{array}$ & $\begin{array}{l}\text { Very fine floc that did not seem } \\
\text { to settle, turbidity of solution } \\
18 \mathrm{ppm} \text {. }\end{array}$ \\
\hline $9 \ldots$ & $\begin{array}{l}\text { NP10, } 1 \text { ppm plus } 1 \text { grain per } \\
\text { gal of alum. }\end{array}$ & Do. \\
\hline
\end{tabular}

Separan has been used as a coagulant to clarify surface water for artificial recharge in the High Plains Underground Water Conservation District (1959a, p. 2-3; 1959b, p. 2-3), Castro County ,Tex. A playa lake was treated with Separan AP30 by spraying from an airplane. Samples of water taken from the lake 3 days after treatment contained $36 \mathrm{ppm}$ suspended solids. Samples taken from a nearby lake for comparison purposes contained $340 \mathrm{ppm}$ suspended solids.

Apparently, physical and chemical differences in the waters and perhaps other factors, such as manner of application and water agitation after treatment, caused Separan to be relatively ineffective in tests in the Grand Prairie region, although it was effective as a coagulant in tests in the High Plains.

Chlorination was the only water-treatment process used in all recharge tests utilizing surface water. Chlorine gas was added to injection water by a vacuum-type solution-feed chlorinator. In those tests using filtered water, the water was chlorinated after coagulation but before filtration. Chlorine dosage ranged from 0 to 50 pounds per day, depending upon the variation in water treatment and the recharge rate used in a particular test. A chlorine residual of $1.0 \mathrm{ppm}$ generally was maintained in the injected water. 
During certain recharge tests, calcium hypochlorite solution was added to the raw surface water before coagulation to control microorganisms. A chlorine residual of 0.5 to $1.0 \mathrm{ppm}$ generally was maintained in the raw water.

Changes in chemical quality of the injected water caused by chlorination were observed in several recharge tests. Group VII samples (table 3) contained an average of about $10 \mathrm{ppm}$ chloride before chlorination. After chlorination with chlorine gas at about $8 \mathrm{ppm}$, injection, and recovery from the aquifer, the water contained about $17 \mathrm{ppm}$ chloride (average chloride content of samples 24 and 25 , table 3). The increase in chloride content of the recovered water nearly equaled the amount of chlorine gas added in the chlorination process. The conversion of chlorine gas to chloride ions is a chemical reaction in which chlorine is reduced and some other substance is oxidized. The chemical analyses are not conclusive in indicating what materials in the aquifer were involved in the oxidation process.

The limited quantities of organic matter and lignite fragments in the aquifer may have been oxidized, releasing gaseous products. Any effects of the release of gaseous products caused by oxidation would have been unnoticed owing to masking by other clogging factors.

Heavy chlorination of injected water should be avoided in recharge operations if possible. Dissolved iron is easily oxidized by chlorine. If pyrite were present in an aquifer it would be oxidized by chlorine and ferrous, ferric, and sulfate ions would be produced. The ferric ions would precipitate as ferric hydroxide and could cause serious clogging. If considerable quantities of gaseous products were formed by the oxidation of organic matter in an aquifer, plugging could result from gas entrainment.

Heavy chlorination of water also would lower the $\mathrm{pH}$ temporarily. This would provide hydrogen ions to bring other constituents into solution. In test 20 (samples 23 and 24 , table 3 ) the calcium content of the recovered water was nearly double that of the injected water. An increase in the bicarbonate content of the recovered water (samples 23 and 24, table 3) also was observed but, as noted, not as great an increase as would be required for the solution of calcium bicarbonate by dissolved carbon dioxide. The effect of a temporary lowering of $\mathrm{pH}$ owing to chlorination might have been great enough to account for more calcium having gone into solution than would be expected from a gain in carbon dioxide content of the water as it moved through the aquifer. 


\section{CHEMICAL ANOMALIES}

Several features of the chemical behavior of the injected water are difficult to explain. In some tests the recovered water removed from the aquifer during recharge-well redevelopment appeared to be substantially lower in silica content than native ground water and in some tests lower than the injected water, as shown in the following table.

\begin{tabular}{|c|c|c|c|}
\hline \multirow[b]{2}{*}{ Test } & \multicolumn{3}{|c|}{$\mathrm{SiO}_{2}$ content (ppm) of sample-- } \\
\hline & $\begin{array}{l}\text { From aquifer } \\
\text { before test }\end{array}$ & $\begin{array}{l}\text { Of injected } \\
\text { water }\end{array}$ & $\begin{array}{l}\text { Recovered } \\
\text { from aquifer } \\
\text { after test }\end{array}$ \\
\hline 2. & 18 & 1.1 & 0. 3 \\
\hline 12 & 21 & 6. 6 & 5. 5 \\
\hline 13 & 5. 5 & 7. 7 & 5. $€$ \\
\hline 14 & 12 & 2. 8 & 1. $E$ \\
\hline 18 & 4. 3 & 1. 4 & 6. $\varepsilon$ \\
\hline 19 & 6. 5 & .9 & 1. 5 \\
\hline 20 & 2. 6 & 1. 8 & 1. $\varepsilon$ \\
\hline
\end{tabular}

Silica deposition may be indicated by these data. As indicated, the chemical behavior of aluminum in the various waters was not readily explained. More data and study of silica and aluminum, as they are, involved in recharge operations, are needed before their chemical behavior as it affects recharge procedures can be fully evaluated.

\section{WELL REDEVELOPMEN'T}

If sufficient water could be injected into a well before recievelopment was required, and the ratio of injected water to that withdrawn from the aquifer during redevelopment was high, well clogging would not be a problem if practical redevelopment techniques were available.

Much attention was given to redevelopment procedures during this investigation. After each recharge test most of the original well specific capacity was regained despite the degree or severity of plugging of the well and aquifer. Practical redevelopment techniques could not be formulated in a step-by-step procedure to be used after each test, because conditions of recharge and clogging were changing constantly and required various trial-and-error methods of redevelopment. However, the various procedures used in well redevelopment during this study may lead to generalized conclusions useful to other recharge operations. 
Sodium hexametaphosphate was used as a redevelopment chemical after most of the recharge tests because of its dispersant action on clays. When sodium hexametaphosphate is added to a solution it dissociates to sodium ions and hexametaphosphate ions. The sodium ions tend to displace calcium ions from exchange positions at the interfaces of clay particles and the solution. The hexametaphosphate ion forms a soluble nonionized complex with calcium, thereby decreasing the ionic concentration of calcium, which helps fill all exchange positions on the clay particles with sodium (W. W. Hastings, written communication, 1957). As a result of ion-exchange process, clay particles disperse and become smaller, resulting in easier removal from the well and aquifer by pumping.

All sodium hexametaphosphate solution and dispersed clogging particles must be removed from the aquifer before recharge is resumed. Otherwise, the dispersed particles will be moved farther into the aquifer and become concentrated at a considerable distance from the point of injection. Furthermore, if there are clay lenses in the aquifer, sodium hexametaphosphate will disperse particles from the clay fraction of the aquifer, adding to the clogging potential.

Most of the clogging by suspended solids observed during this study was localized to within 2 or 3 feet of the recharge well, and it was not necessary to move sodium hexametaphosphate solution a great distance into the aquifer. Thus, dispersed clay particles and the sodium hexametaphosphate solution were easily removed from the well and aquifer by pumping.

Variations of the following procedure were used to apply sodium hexametaphosphate to the recharge well for redevelopment. About 100 pounds of the chemical was dissolved in about 100 gallons of water, and approximately 50 gallons of the solution was placed directly in the recharge well. The remaining 50 gallons was distributed equally into the 4 feeder wells (fig. 3) when using recharge well 1 or into the packing material around the outside of the screen when using recharge well 2 .

Occasionally, this was followed by the addition of 100 to 3,000 gallons of water depending upon how far from the recharge well it was desired to move the sodium hexametaphosphate solution. The well was surged by turning the pump on and off for short periods of time. The period of time the solution remained in the well and aquifer was varied as different redevelopment procedures were tried after recharge tests.

The contact period ranged from a few minutes to 24 hours. The longer contact period generally was more effective in removal of 
clogging material. The recharge well was then alternately pumped and surged until the sodium hexametaphosphate solution had been removed from the well and aquifer. Occasionally, the concentration of the solution added for redevelopment was greatly increased. As much as 200 pounds of sodium hexametaphosphate was dissolved in about 100 gallons of water and added to the recharge well. In later tests, redevelopment was effected by dissolving 100 to 300 pounds of sodium hexametaphosphate in 1,000 to 5,000 gallons of water and adding this relatively dilute solution to the recharge well.

In several redevelopment trials, water recovered from the recharge well was very muddy, as though large quantities of clogging material were being removed from the aquifer. Yet, there was no significant increase in specific capacity of the well.

The hydration shell around a sodium ion in solution is relatively large, and the effective diameter of a particle surrounded by bound sodium ions is greater than the same particle surrounded by bound calcium ions (W. W. Hastings, written communication, 1957). Thus, when sodium hexametaphosphate solution enters into ion-exchange reactions, certain clay particles may tend to disperse and shrink while others may tend to swell.

Calcium chloride was tried as a redevelopment chemical to recoagulate and shrink those clay particles that may have been adversely affected by the addition of sodium hexametaphosphate. About 100 pounds of commercial-grade calcium chloride was dissolved in/about 50 gallons of water and added to the recharge well. The specific capacity of the well was increased about $9 \mathrm{gpm}$ per foot by the calcium chloride treatment. However, significant increases in specific capacity were observed in only one other redevelopment test as a result of using calcium chloride as a redevelopment chemical. No enlarged clogging particles may have been in the aquifer; hence, the ineffectiveness of later redevelopment tests with calcium chloride. It cannot be conclusively established that calcium chloride may be used successfully as a redevelopment chemical, because it was not possible to duplicate favorable results.

Calcium chloride was added to the injection supply during test 3 so that the resultant water would have about the same relative percentage of monovalent cations as the ground water. After test 3 sodium hexametaphosphate was used as a redevelopment chemical. During preparations for redevelopment, the container used to mix the calcium chloride solution was used to mix the sodium hexametaphosphate solution. A heavy, thick, white precipitate formed in the container when portions of the two solutions became mixed. Lab- 
oratory tests showed that a concentrated sodium hexametaphosphate solution mixed with a relatively dilute solution of calcium chloride would form a white precipitate, but, if the amount of calcium chloride in solution was in excess of the sodium hexametaphosphate in solution, a precipitate would not form. The precipitate was soluble in dilute hydrochloric acid.

Putting a relatively concentrated solution of sodium hexametaphosphate in the recharge well after injection of water containing calcium chloride evidently could produce a precipitate. The two solutions mixed in laboratory tests were concentrated and of small volume, whereas, solutions in the well and aquifer were comparatively dilute and of large volume. However, rather than risk further plugging of the well and aquifer by precipitation of the redevelopment chemical, the well was acidized.

Sodium hexametaphosphate proved to be an effective, easily applied, and economical redevelopment chemical. Its dispersing action on suspended solids and precipitated iron facilitated their removal from the well and aquifer, thus, restoring the preinjection specific capacity. Sodium hexametaphosphate was also effective in redevelopment of the well when the well and aquifer were plugged by air entrainment (Sniegocki, 1959). Apparently, detergent action of the sodium hexametaphosphate changed the surface tension of the water in the aquifer, permitting removal of air bubbles from interstitial spaces by pumping.

Inhibited technical-grade hydrochloric acid was used to acidize the recharge well after observation of the precipitate in the mixing container. Three 15-gallon carboys of acid were emptied into the recharge well and one 15-gallon carboy of acid was divided into equal parts and poured into the four feeder wells. A few hundred gallons of water was added to flush the acid into the wells. After a 24-hour contact period, the well was alternately surged and pumped to completely remove the acid. The specific capacity of the recharge well had been $31 \mathrm{gpm}$ per foot before beginning test 3 and was $12 \mathrm{gpm}$ per foot after injecting about 40,000 gallons of water. The specific capacity of the recharge well after acidizing was $25 \mathrm{gpm}$ per foot. However, some of the improvement may have resulted from the addition of calcium chloride to the injected water and the addition of sodium hexametaphosphate to the well before acidizing.

A summary of the specific capacity observed in recharge wells 1 and 2 (Sniegocki and others, 1963) before and after each recharge test is shown in the following table. 


\begin{tabular}{|c|c|c|c|}
\hline \multirow{2}{*}{ Test } & \multirow{2}{*}{$\begin{array}{l}\text { Water injected } \\
\text { (gallons) }\end{array}$} & \multicolumn{2}{|c|}{$\begin{array}{l}\text { Specific capacity } \\
\text { (gpm per ft) - }\end{array}$} \\
\hline & & Before test & After test \\
\hline \multicolumn{4}{|c|}{ Recharge well 1} \\
\hline 10 & $\begin{array}{r}3,619,990 \\
2,528,900 \\
39,800 \\
46,250 \\
104,100 \\
105,900 \\
109,800 \\
178,500 \\
158,200 \\
972,840 \\
81,900 \\
180,600 \\
6,128,800 \\
84,500 \\
224,400 \\
229,100 \\
162,000\end{array}$ & $\begin{array}{l}21 \\
25 \\
31 \\
25 \\
26 \\
27 \\
25 \\
30 \\
27 \\
27 \\
25 \\
30 \\
33 \\
31 \\
28 \\
26 \\
23\end{array}$ & $\begin{array}{r}7 \\
7 \\
12 \\
11 \\
25 \\
12 \\
30 \\
27 \\
12 \\
8 \\
12 \\
33 \\
18 \\
21 \\
26 \\
23 \\
22\end{array}$ \\
\hline
\end{tabular}

Recharge well 2

\begin{tabular}{r|r|r|r}
\hline 18 & 534,700 & 27 & 17 \\
20 & $\begin{array}{r}788,670 \\
21\end{array}$ & 26 & 20 \\
22 & 807,600 & 17 & 20 \\
23 & 216,250 & 15 & 8 \\
\hline
\end{tabular}

Although redevelopment generally was successful in both wells, recharge well 2 was not restored to equal or better than pretest specific capacity except after test 22 . Tests 18 through 23 generally were of longer duration than tests 1 through 17 , and the water injected in recharge well 2 generally received considerably less treatment than that injected in well 1. These differences in injection procedures, the absence of feeder wells around recharge well 2, and differences in construction of the two recharge wells may account for the difficulty experienced in redevelopment of recharge well 2 (Sniegocki and others, 1963). The failure to redevelop recharge well 2 to equal or better than pretest specific capacity contributed to the severe clogging observed during successive tests. The general deterioration of recharge well 2 as injection tests continued prompted an extensive attempt at redevelopment after recharge test 22 was completed.

About 100 pounds of sodium hexametaphosphate dissolved in 1,000 gallons of water was put into the well. After a 24-hour period the well was surged and pumped, and a test showed the well had a specific capacity of about $8 \mathrm{gpm}$ per ft. About 500 pounds of sodium hexa- 
metaphosphate dissolved in about 5,000 gallons of water was put into the well. The next day about 17,000 gallons of water was pumped from the well, and the specific capacity was $11 \mathrm{gpm}$ per $\mathrm{ft}$. Three weeks later 2,500 pounds of sodium hexametaphosphate dissolved in approximately 22,000 gallons of water was added to the recharge well. The well was alternately surged and pumped for 2 days, and the specific capacity was estimated to be about $16 \mathrm{gpm}$ per $\mathrm{ft}$ at the end of this period.

The pump was pulled from the recharge well and preparations were made for agitating the well with a surge block. A large wire brush was placed in the recharge well and rotated inside the screen as the brush was lowered and raised. Following this, the well was surged, bailed, and pumped. During surging, 200 pounds of sodium hexametaphosphate dissolved in approximately 2,000 gallons of water was added to the recharge well.

A recording gage installed in an observation well 20 feet from the recharge well was in operation during the surging, bailing, and pumping period. Agitation of the surge block caused the water level in the observation well to fluctuate as much as 0.3 foot (pl. 1). Notes on plate 1 relate the changes in water level in the observation well to the redevelopment operations in the recharge well.

The specific capacity of the recharge well was abous $17 \mathrm{gpm}$ per $\mathrm{ft}$ after two periods of surging. After four more intervals of surging and removal of the sodium hexametaphosphate solution by pumping, the specific capacity of the recharge well was about $20 \mathrm{gpm}$ per $\mathrm{ft}$. The increase in specific capacity of only $3 \mathrm{gpm}$ per $\mathrm{ft}$ between surging intervals made further surging unwarranted, and redevelopment operations were discontinued.

The well was not redeveloped to as high a specific capacity ( $27 \mathrm{gpm}$ per $\mathrm{ft}$ ) as it had before it was used for recharge tests. However, restoration of more than $18 \mathrm{gpm}$ per $\mathrm{ft}$ specific capacity was one of the best recoveries attained in any redevelopment test, and in no other instance was the well as severely plugged before attempting redevelopment.

The life of a recharge well may be extended if it can also be used as a production well. Recharge test 11 was completed in February 1957. The specific capacity of the recharge well was $25 \mathrm{gpm}$ per $\mathrm{ft}$ before injection and $12 \mathrm{gpm}$ per $\mathrm{ft}$ after completing the test. In April 1957, redevelopment was tried with calcium hypochlorite and sodium hexametaphosphate solutions, and the specific capacity of the well was increased to about $20 \mathrm{gpm}$ per $\mathrm{ft}$. The recharge well was pumped for rice irrigation in May and June to determine whether or not prolonged pumping would improve the specific capacity. After pumping for about 3 weeks at approximately $250 \mathrm{gpm}$, the specific capacity was 
estimated to be $27 \mathrm{gpm}$ per $\mathrm{ft}$. Rice irrigation was discontinued, and the water level in the recharge well was allowed to recover. In October 1957, the specific capacity of the recharge well was $30 \mathrm{gpm}$ per ft.

Also, it is possible that the specific capacity of a recharge well may be improved by recharge. Recharge test 12 was made in October 1957, with completely treated water. The specific capacity of the well was $30 \mathrm{gpm}$ per $\mathrm{ft}$ before injection and $33 \mathrm{gpm}$ per $\mathrm{ft}$ after. This could have been the result of no plugging during injection, increased water in storage in the aquifer, and reversal of water movement through the aquifer caused by pumping for irrigation in May and June.

\section{CONCLUSIONS}

Water will attain a certain physical and chemical quality after a period of time in response to its environment. Generally, the water will maintain this character as long as the environment remains unchanged. An environment should be studied in detail to estimate its effects on water. Artificial recharge through wells rapidly transports water from one environment into another that generally is very different. Therefore, if any degree of understanding of or control over changes in the physical and chemical quality of recharged water is to be gained, it is essential that physical and chemical relationships among waters and their environments be considered.

Knowledge of the composition of a ground-water reservoir depends upon spot sampling, usually done by test drilling. Although considerable effort was expended during this study to determine the hydrogeological situation at the recharge site, more attention should have been concentrated on quantitative definitions of the chemical nature of the deposits of Quaternary age. Detailed knowledge of the physical and chemical character of an aquifer will greatly enhance the chances for successful long-term injection of water through wells in any area.

If injected water loses solutes by precipitation, chemical clogging of the aquifer may occur. Changes in the solute content of injected water may be influenced by the native ground water as well as by the aquifer; hence, it is important that the chemical quality of the recharge supply and the native ground water be known in detail in addition to the chemical character of the aquifer materials.

Chemical compatibility of the native ground water and the recharge water can be evaluated by means of chemical-equilibrium diagrams for ground-water systems described by Hem (1960). Changes in chemical quality of the injected water imposed by the new environment may cause changes in water compatibility. It may be necessary to recharge for a short period, collect samples of the injected and native 
ground water before, during, and after recharge, chemically analyze these samples, interpret these data by use of chemical-equilibrium diagrams, and then devise measures to avert chemical clogging, if needed. For example, during this study it was observed that carbon dioxide apparently was being depleted in the aquifer by recharge. This was determined by chemical analysis of samples of water collected during recharge tests. Chemical-equilibrium diagrams indicated that depletion of the carbon dioxide in the aquifer may result in precipitation of calcium carbonate during recharge operations. Continued recharge may require changing the chemical quality of the injected water to offset carbon dioxide depletion. Carbon dioxide gas added to the recharge water would have provided an easily applied and effective chemical additive for this purpose.

Conclusive evidence was not obtained during this study that ion exchange resulted when the relative abundance of multivalent cations in the surrounding solution was increased as a result of recharge. The phenomenon has been observed in artificial-recharge studies in California. Wellhead pressures were greatly increased when a slug of sodium chloride, introduced into the well as a tracer, caused dispersal of the clay fraction of the aquifer (California State Water Pollution Control Board, 1954, p. 60-61).

Ion exchange is a relatively common reaction and should be considered a potential cause of clogging during recharge. The cation ratio of the injected water can be changed easily and economically, under some conditions, by the addition of chemicals. However, the chemicals added may participate in other chemical reactions that could cause clogging.

Chemical plugging of a recharge well and aquifer generally will be slow and, thus, not hydraulically detectable until after recharging for a considerable period of time. Long-term recharge would place the injected water a great distance from the recharge well. Consequently, chemical plugging would occur over a relatively large portion of the aquifer. This is in contrast to mechanical plugging by suspended solids, air entrainment, and micro-organisms, which generally would be localized to within a few feet of the recharge well. Redevelopment of the recharge well after chemical plugging would be difficult, because the plugging occurs through a large volume of the aquifer.

Plugging caused by iron precipitation, as postulated in this report, would not be serious if the injected water and enough native ground water were removed from the aquifer to reverse the reaction. The improvement in specific eapacity of the recharge well after prolonged pumping indicated that dual-purpose use (recharge and production) was a desirable practice when recharging through wells.

Two conditions unfavorable to recharge that are related to the 
chemical aspects of this study could not be overcome--maintaining an injection supply of constant chemical quality from test to test and restoration of the aquifer to pretest conditions. Complete and conclusive evaluation of the geochemistry of recharge through wells cannot be made unless these conditions are met.

Generally, the injected water was removed from the aquifer after a recharge test in an attempt to restore native conditions in the aquifer. The water injected during short-term tests was easily removed by pumping. For example, if 100,000 gallons of water was injected during a 6-hour test, pumping about 300,000 gallons of water from the aquifer exhausted the injected water. Hydraulic conditions in the aquifer were restored reasonably well by allowing sufficient time before new recharge tests were begun. However, it would have been necessary to pump approximately 20 million gallons of water from the aquifer after long-term tests to remove the injected water. In addition, a longer recovery period would have been required between tests. It was technically and economically impractical to attempt restoration of native conditions in the aquifer after long-term injection tests. Consequently, chemical definition of water in the aquifer was not as complete as desired.

Maintaining constant chemical quality of the recharge supply was not a problem during short-term injection tests. During long-term tests, changing weather conditions and problems of operation of watertreatment equipment caused uncontrollable changes in chemical quality of the recharge supply. These factors intensified changes in water quality between recharge tests. Injection of water of changing quality in to the aquifer where it came in contact with water remaining from the previous test further complicated interpretation of the geochemistry of recharge.

Generally, most attempts at recharge through wells are made without due consideration of the chemistry involved. Natural recharge is a slow process, during which the infiltrating water passes through a large volume of overburden and aquifer material, and time permits natural chemical adjustments to occur in the water and ground-water reservoir as infiltration proceeds. Artificial recharge is a rapid process, and the same chemical changes in the water that did not impede natural recharge because they took place above the water table or through a wide zone of the aquifer, may impede artificial recharge to a point of impracticality. All recharge operations, whether experimental or operational, should establish chemical-quality control of the system. This control can be eliminated or greatly reduced once it is established that chemical changes in the waters and aquifer are not creating recharge problems.

Small samples of the injected water should be collected frequently 
and composited for a complete chemical analysis. This is preferable to large samples collected less frequently and not composited. Chemical definition of water as it existed in the aquifer may require analysis of the sample immediately after collection. Changes in $\mathrm{pH}$ and precipitation of solutes were observed in samples that were allowed to stand for a week or two before analysis. Also, complete analyses should be made of all samples collected until it can be established conclusively that certain constituents in the water have no influence upon recharge operations.

Adequate chemical-quality control of recharge operations will result in a large volume of data. Organization and study of these data may become unwieldy and difficult because of their bulk. Maximum use should be made of the methods of evaluation outlined by Hem $(1959$, p. 154-200).

\section{SELECTED REFERENCES}

California state Water Pollution Control Board, 1954, Report on the investigation of travel of pollution: Sacramento, Calif., Pub. 11, 218 p.

Engler, Kyle, Bayley, F. H., 3d, and Sniegocki, R. T., 1963, Studies of artificial recharge in the Grand Prairie region, Arkansas-environment and history: U.S. Geol. Survey Water-Supply Paper 1615-A, 32 p.

Hem, J. D., 1959, Study and interpretation of the chemical characteristics of natural water: U.S. Geol. Survey Water-Supply Paper 1472, 269 p., 2 pls., 40 figs.

1960, Chemical equilibrium diagrams for ground-water systems: Internat. Assoc. Sci. Hydrology Bull., v. 19, p. 45-53.

1961a, Calculation and use of ion activity: U.S. Geol. Survey WaterSupply Paper 1535-C, 17 p., 1 pl., 2 figs.

1961b, Stability field diagrams as aids in iron chemistry studies: Am. Water Works Assoc. Jour., v. 53, no. 2, p. 211-232.

Hem, J. D., and Cropper, W. H., 1959, Survey of ferrous-ferric chemical equilibria and redox potentials: U.S. Geol. Survey Water-Supply Paper 1459-A, 31 p., 2 figs.

High Plains Underground Water Conservation District No. 1, 1959a, Chemical offers new approach to solving problem of sediments suspended in lake water: The Cross Section, v. 5, no. 11, p. 2-3.

$1959 \mathrm{~b}$, Data reveal flocculating chemical clears lake water of most suspended matter: The Cross Section, v. 6, no. 1, p. 2-3.

Langelier, W. F., 1936, The analytical control of anti-corrosion water treatment: Am. Water Works Assoc. Jour., v. 28, no. 10, p. 1500-1521.

Sniegocki, R. T., 1959, Plugging by air entrainment in artificial-recharge tests: Water Well Jour., v. 13, no. 6, p. 17-18, 43-44.

1963, Hydrogeology of a part of the Grand Prairie region, Arkansas: II.S. Geol. Survey Water-Supply Paper 1615-B. (In press.)

Sniegocki, R. T., Bayley, F. H., 3d, and Engler, Kyle, 1963, Equipment and controls used in studies of artificial recharge in the Grand Prairie region, Arkansas: U.S. Geol. Survey Water-Supply Paper 1615-C, 39 p.

Sundstrom, R. W., and Hood, J. W., 1952, Results of artificial recharge of the ground-water reservoir at El Paso, Texas: Texas Board Water Engineers Bull. 5206, 19 p. 